\title{
Molecular mechanisms of action and prediction of response to oxaliplatin in colorectal cancer cells
}

\author{
D Arango*, 1,2, AJ Wilson', Q Shi', GA Corner', MJ Arañes', C Nicholas', M Lesser', JM Mariadason' and \\ LH Augenlicht'
}

'Oncology Department, Albert Einstein Cancer Center, Montefiore Medical Center, I I I East 2 I Oth St, Bronx, NY 10467, USA; ${ }^{2}$ Department of Medical Genetics, Biomedicum Helsinki, PO Box 63 (Haartmaninkatu 8), FIN-000 I 4 University of Helsinki, Finland; ${ }^{3}$ School of Public Health, New York Medical College, Valhalla, New York, USA; ${ }^{4}$ Biostatistics Unit, North Shore-Long Island Jewish Research Institute, Manhasset, NY, USA

\begin{abstract}
The platinum compound oxaliplatin has been shown to be an effective chemotherapeutic agent for the treatment of colorectal cancer. In this study, we investigate the molecular mechanisms of action of oxaliplatin to identify means of predicting response to this agent. Exposure of colon cancer cells to oxaliplatin resulted in G2/M arrest and apoptosis. Immunofluorescent staining demonstrated that the apoptotic cascade initiated by oxaliplatin is characterised by translocation of Bax to the mitochondria and cytochrome $c$ release into the cytosol. Oxaliplatin treatment resulted in caspase 3 activation and oxaliplatin-induced apoptosis was abrogated by inhibition of caspase activity with z-VAD-fmk, but was independent of Fas/FasL association. Targeted inactivation of Bax or p53 in $\mathrm{HCTI}$ I 6 cells resulted in significantly increased resistance to oxaliplatin. However, the mutational status of p53 was unable to predict response to oxaliplatin in a panel of 30 different colorectal cancer cell lines. In contrast, the expression profile of these 30 cell lines, assessed using a 9216-sequence cDNA microarray, successfully predicted the apoptotic response to oxaliplatin. A leave-one-out cross-validation approach was used to demonstrate a significant correlation between experimentally observed and expression profile predicted apoptosis in response to clinically achievable doses of oxaliplatin $(R=0.53 ; P=0.002)$. In addition, these microarray experiments identified several genes involved in control of apoptosis and DNA damage repair that were significantly correlated with response to oxaliplatin.

British Journal of Cancer (2004) 91, 1931-1946. doi:I0.1038/sj.bjc.6602215 www.bjcancer.com
\end{abstract}

Published online 16 November 2004

(c) 2004 Cancer Research UK

Keywords: oxaliplatin; apoptosis; Bax; p53; colorectal cancer; microarray

Oxaliplatin is a third generation diaminocyclohexane (DACH) platinum compound that forms mainly intrastrand links between two adjacent guanine residues or a guanine and an adenine, disrupting DNA replication and transcription (Fink et al, 1997). Although the related platinum compounds, cisplatin and carboplatin, are generally ineffective in the treatment of colorectal cancer, oxaliplatin has been shown to be effective in the treatment of this disease and it is commonly used to treat patients unresponsive to 5-fluorouracil (5FU) based therapy. However, the details underlying the cytotoxic effects of oxaliplatin remain poorly understood.

Exposure of tumour cells to several chemotherapeutic agents, including oxaliplatin, has been shown to induce programmed cell death or apoptosis (Searle et al, 1975; Lowe and Lin, 2000; Gourdier et al, 2002; Johnstone et al, 2002). In mammalian cells, the signalling cascades leading to apoptosis can be divided into two broad groups. The intrinsic pathway is characterised by the central role of the mitochondria in the initiation of the caspase cascade executing the apoptotic program (Desagher and Martinou, 2000). Pro- and antiapoptotic Bcl-2 family members play a pivotal

*Correspondence: D Arango; E-mail: diego.arango@helsinki.fi Received 17 June 2004; revised 23 August 2004; accepted 13 September 2004; published online 16 November 2004 role in the intrinsic apoptotic cascade (Narita et al, 1998; Gross et al, 1999). Upon exposure to some apoptotic stimuli, proapoptotic Bcl-2 family members such as Bax, which normally reside in the cytosol, are relocated to the outer mitochondrial membrane where they lead to the release of apoptotic factors from the mitochondria and ultimately to caspase activation and an apoptotic cell death (Li et al, 1997; Zou et al, 1997). The tumour suppressor gene p53 has been shown to directly regulate the expression levels of Bax (Miyashita and Reed, 1995), and both p53 and Bax have been shown to be important determinants of the cellular response to chemotherapeutic agents (Bunz et al, 1999; Zhang et al, 2000). In the extrinsic pathway, however, caspase activation is initiated by death receptors on the cell surface (Ashkenazi and Dixit, 1998). Chemotherapeutic agents are known to induce apoptosis by either of these two mechanisms (Lowe and Lin, 2000; Johnstone et al, 2002).

While significant progress has been made in the identification of markers predicting response to 5FU and CPT-11, two additional chemotherapeutic agents commonly used for colorectal cancer treatment (Augenlicht et al, 1997; Bunz et al, 1999; Salonga et al, 2000; Arango and Augenlicht, 2001; Arango et al, 2001, 2003), there is great need for markers that allow discrimination of tumours that vary in their sensitivity to oxaliplatin. The tumour suppressor p53 has a pivotal role in determining the cellular sensitivity to a number of chemotherapeutic agents, including 5FU and CPT-11 
(Bunz et al, 1999; Arango et al, 2001, 2003; Magrini et al, 2002). In this study we investigated the potential of this genetic marker to predict response to oxaliplatin in vitro. Previous studies have shown that simultaneous analysis of multiple independent markers capable of predicting response to chemotherapy significantly improves the accuracy of the predictions (Salonga et al, 2000; Arango et al, 2001). cDNA microarray analysis allows the assessment of the level of expression of thousands of genes simultaneously, and its potential to predict response of tumour cells to chemotherapeutic agents has been recently demonstrated (Scherf et al, 2000; Kihara et al, 2001; Zembutsu et al, 2002; Mariadason et al, 2003). Therefore, we hypothesised that the expression profile of untreated tumour cells could be used to predict sensitivity to oxaliplatin, and used a leave-one-out crossvalidation approach to formally demonstrate the accuracy of this approach in a panel of 30 colorectal cancer cell lines.

\section{MATERIALS AND METHODS}

\section{Cell culture}

HCT116 colon carcinoma cells and isogenic derivatives with a targeted inactivation of $\mathrm{p} 53$ or Bax (Bunz et al, 1998; Zhang et al, 2000) were a gift of Dr Vogelstein (Johns Hopkins University School of Medicine). Cells were maintained in minimum essential medium (MEM) supplemented with 10\% fetal bovine serum (FBS), $1 \times$ antibiotic/antimycotic $\left(100 \mathrm{U} \mathrm{ml}^{-1}\right.$ streptomycin sulphate, $100 \mathrm{U} \mathrm{ml}^{-1}$ penicillin $\mathrm{G}$ sodium and $0.25 \mu \mathrm{g} \mathrm{ml}^{-1}$ amphotericin B), $100 \mu \mathrm{M}$ nonessential amino acids and $10 \mathrm{mM}$ HEPES buffer solution (all from Invitrogen Corporation, Carlsbad, CA, USA).

\section{Cell cycle and apoptosis}

For analysis of cell cycle, $2 \times 10^{5}$ HCT116 cells were seeded on sixwell plates in triplicate and allowed to attach for $24 \mathrm{~h}$. For timeresponse studies cells were treated with 5 or $10 \mu \mathrm{M}$ oxaliplatin (supplied by Sanofi-Synthelabo, New York, NY, USA) for 12, 24, 48 and $72 \mathrm{~h}$. For concentration-response experiments, cells were treated for $72 \mathrm{~h}$ with $5,10,15,20,25$ and $50 \mu \mathrm{m}$ oxaliplatin. Both attached and floating cells were harvested, washed twice with $2 \mathrm{ml}$ of PBS and resuspended in PBS containing $50 \mu \mathrm{g} \mathrm{ml}^{-1}$ propidium iodine (PI), $0.1 \%$ sodium citrate and $0.1 \%$ Triton X-100. Cells were stained overnight at $4{ }^{\circ} \mathrm{C}$ and a minimum of 10000 cells analysed for DNA content using a Becton Dickinson FACScan (Becton Dickinson Immunocytometry Systems, San Jose, CA, USA). The proportion of cells in G0/G1, S phase and G2/M were quantified using ModFit 2.0 (Verity Software House, Topsahm, ME, USA). Apoptosis induced by oxaliplatin treatment was assessed by the nuclear morphology of floating cells. HCT116 cells $\left(1.6 \times 10^{6}\right)$ were seeded on T75 culture flasks and allowed to attach to the substrate for $24 \mathrm{~h}$ before exposure to $25 \mu \mathrm{m}$ oxaliplatin for $48 \mathrm{~h}$. Floating cells were collected, pelleted and re-suspended in $1 \mu \mathrm{M}$ DAPI (Sigma, St Louis, MO, USA) in PBS. Micrographs of DAPI stained nuclei were captured with a SPOT RT Diagnostic Instruments CCD camera (Diagnostic Instruments, Sterling Heights, MI, USA) attached to a BX60 Olympus fluorescence microscope (Olympus, Melville, NY, USA). Quantification of apoptosis was carried out by PI staining and flow cytometric analysis of the proportion of cells with a subdiploid content of DNA using WinList 2.0 (Verity Software House, Topsahm, ME, USA). In some experiments, cell cultures were preincubated with $2 \mu \mathrm{g} \mathrm{ml}^{-1}$ anti-Fas receptor antibody ZB4 (Upstate Biotechnology, Lake Placid, NY, USA) or $1 \mu \mathrm{g} \mathrm{ml}^{-1}$ antiFas ligand antibody NOK-1 (BD Biosciences Pharmingen, San Diego, CA, USA) for $1 \mathrm{~h}$ before oxaliplatin cotreatment. Some HCT116 cultures were coincubated with the pan-Caspase inhibitor z-VAD-fmk (Calbiochem, La Jolla, CA, USA) at the final concentrations indicated in the text.

\section{Caspase 3 activation}

HCT116 cells $\left(2 \times 10^{5}\right)$ were seeded on six-well plates in triplicate, allowed to attach for $24 \mathrm{~h}$, and then treated with $25 \mu \mathrm{m}$ oxaliplatin. After $72 \mathrm{~h}$ of treatment, floating cells were collected and pooled with the attached cells harvested by trypsinisation. Cells were washed with PBS, resuspended in CytoFix/CytoPerm (Pharmingen, San Diego, CA, USA), incubated for $30 \mathrm{~min}$ on ice and then washed with Perm/Wash buffer (Pharmingen, San Diego, CA, USA) and resuspended in $100 \mu \mathrm{l}$ of Perm/Wash buffer. In total, $20 \mu \mathrm{l}$ of phycoerythrin (PE)-conjugated anti-active caspase-3 (Pharmingen, San Diego, CA, USA) were added and cells were incubated at $4^{\circ} \mathrm{C}$ in the dark for $30 \mathrm{~min}$, washed with Perm/Wash buffer and resuspended in $400 \mu \mathrm{l}$ of Perm/Wash buffer. Samples were analysed using a Becton Dickinson FACScan, measuring logarithmic PE fluorescence in the FL-2 channel in a minimum of 10000 cells.

\section{Western blotting}

HCT116 cells seeded in $75 \mathrm{~cm}^{2}$ flasks were treated with $10 \mu \mathrm{M}$ oxaliplatin for $0,6,12,16$ or $24 \mathrm{~h}$ and then rinsed with PBS twice, harvested and resuspended in $300 \mu \mathrm{l}$ of RIPA lysis buffer ( $1 \%$ NP-40, $1 \%$ sodium deoxycholate, $0.1 \%$ SDS, $0.15 \mathrm{M} \mathrm{NaCl}, 0.01 \mathrm{~m}$ sodium phosphate $\mathrm{pH}$ 7.2, $2 \mathrm{~mm}$ EDTA, $50 \mathrm{~mm}$ sodium fluoride, $0.2 \mathrm{~mm}$ sodium vanadate and $100 \mathrm{U} \mathrm{ml}^{-1}$ aprotinin). The cell suspension was vortexed and kept on ice for $30 \mathrm{~min}$ before cell debris was pelleted and the supernatant transferred to a new tube. SDS - polyacrylamide gel electrophoresis sample loading buffer $(6 \times)$ was added to $20 \mu \mathrm{g}$ aliquots and loaded on $15 \%$ tris- $\mathrm{HCl}$ precast gels (BioRad, Hercules, CA, USA). Fractionated proteins were transferred to a PVDF membrane (Amersham, Piscataway, NJ, USA) and blocked with $10 \%$ nonfat milk for $1 \mathrm{~h}$. Membranes were then probed at room temperature with the appropriate primary antibody in $5 \%$ nonfat milk for $1 \mathrm{~h}$ with the following antibodies: anti-p53 (Santa Cruz, DO-1, 1/7000), anti-p21 ${ }^{\text {Cip1/WAF1 }}$ (Santa Cruz, H-164, 1/200) and anti- $\beta$-actin (Sigma, clone AC74, 1/1000). Membranes were washed three times with washing buffer (PBS with $0.1 \%$ Tween 20) and then probed with the appropriate peroxidase-conjugated secondary antibody for $1 \mathrm{~h}$ (all from Roche Diagnostics/Boehringer Mannheim Corporation, Indianapolis, IN, USA). The secondary antibody was washed three times with washing buffer and the signal was developed using ECL Plus Western Blotting Detection Method (Amersham, Piscataway, NJ, USA). Detection was carried out using a Storm PhosphorImager and quantified using ImageQuant software (Molecular Dynamics, Sunnyvale, CA, USA). Protein levels were standardised using the signal from the $\beta$-actin probe.

\section{Immunofluorescence analysis}

Cells were cultured overnight on preferred glass coverslips (Fisher, Pittsburgh, PA, USA), and then treated with 10,20 or $50 \mu \mathrm{M}$ oxaliplatin. The cells were fixed for $15 \mathrm{~min}$ in $4 \%$ paraformaldehyde (Electron Microscopy Services, Ft Washington, PA, USA), permeabilised with $0.5 \%$ Triton X-100/PBS for $5 \mathrm{~min}$ and then incubated for $1 \mathrm{~h}$ in a $1 \%$ BSA/PBS blocking solution. To detect $\mathrm{BAX}$, cells were incubated for $3 \mathrm{~h}$ with a rabbit polyclonal IgG that recognised the N-terminal region (Upstate Biotechnology, Lake Placid, NY, USA; 1:100 dilution), followed by exposure to a goat Cy3-conjugated anti-rabbit secondary antibody (Amersham, Piscataway, NJ, USA). To detect mitochondria, a mouse monoclonal Hsp60 antibody was used (Santa Cruz Biotechnology, Santa Cruz, CA, USA; 1:200), the binding of which was detected by a goat anti-mouse FITC-conjugated secondary antibody (Roche Diagnostics/Boehringer Mannheim Corporation, Indianapolis, IN, USA). Cytochrome $c$ was detected utilising a mouse monoclonal 
anti-cytochrome $c$ IgG (Pharmingen, San Diego, CA, USA; $1: 200$ ) followed by exposure to a goat anti-mouse Cy5-conjugated secondary antibody (Amersham Biosciences, Piscataway, NJ, USA). All secondary antibodies were used at a dilution of $1: 200$ for $1 \mathrm{~h}$. All washes were performed with PBS. To visualise nuclei, cells were stained with DAPI (Sigma, St Louis, MO, USA; 4',6diamidino-2-phenylindole). Fluorescent images were captured with a SPOT RT Diagnostic Instruments CCD camera (Diagnostic Instruments, Sterling Heights, MI, USA) attached to a BX60 Olympus fluorescence microscope (Olympus, Melville, NY, USA). The proportion of apoptotic cells was quantified by scoring the number of cells simultaneously exhibiting Bax relocalisation and cytochrome $c$ release in 200 cells.

\section{Growth/cytotoxicity assay}

The concentration of oxaliplatin resulting in 50\% inhibition of control growth $\left(\mathrm{GI}_{50}\right)$ in response to oxaliplatin was calculated using the sulphorhodamine $\mathrm{B}$ method according to the protocol used by the NCI in vitro Anticancer Drug Discovery Screen Program (Skehan et al, 1990). Ten thousand cells per well were seeded in 96-well plates and $24 \mathrm{~h}$ later exposed to $0,0.0125,0.025$, $0.125,0.25,1.25,2.5,6.25,12.5,25,50$ and $125 \mu \mathrm{M}$ oxaliplatin for $72 \mathrm{~h}$. The $\mathrm{GI}_{50}$ concentrations were calculated as described (Skehan et al, 1990; Arango et al, 2003; Mariadason et al, 2003) using Prism 3.0 software (GraphPad, San Diego, CA, USA).

\section{Clonogenic assay}

One million cells were seeded in T25 flasks and $24 \mathrm{~h}$ later exposed to $0,2.5,3,3.5$ or $4 \mu \mathrm{M}$ oxaliplatin for $9 \mathrm{~h}$. Cells were then trypsinised and 500 cells reseeded in six-well plates in triplicate. Colonies were allowed to form for 2 weeks and then plates were washed and air-dried. Colonies were stained with $0.1 \%$ crystal violet, washed three times with distilled water, and air-dried. Plates were scanned using a Perfection 1250 scanner (Epson America Inc., Long Beach, CA, USA) and the number of colonies quantified using Total Lab 1.1 software (Nonlinear Dynamics, Durham, NC, USA).

\section{Assessment of p53 status}

The mutational status of the 30 colorectal cancer cell lines in the panel used has been previously reported (Mariadason et al, 2003). Sequencing of the hotspots for p53 mutations (exons 5-8) in T84 cells found no mutations (Mariadason et al, 2003). Moreover, Western blot analysis demonstrated that T84 cells have low basal p53 levels, which is characteristic of colorectal cancer cells with a wild-type p53 gene. However, subsequent analyses showed that, unlike other wild-type $\mathrm{p} 53$ cell lines in the panel, T84 cells failed to upregulate the $\mathrm{p} 53$ target gene $\mathrm{p} 21^{\text {Waf1/Cip } 1}$ in response to cytotoxic insult ( 5 and $50 \mu \mathrm{m} 5-\mathrm{FU}$ for $24 \mathrm{~h}-$ not shown). We, therefore, sequenced the remaining of the p53 coding sequence in this cell line and found a missense mutation in exon 4 (codon 60, CCA $\rightarrow$ CTA; Pro $\rightarrow$ Leu). Moreover, this mutation has previously been identified in human malignancies, further suggesting that this mutation disrupts p53 function (http://p53.curie.fr). The p53 primers used in the PCR reactions were exon 2: CGACTGTCCA GCTTTGTGC and CCCGTGACTCAGAGAGGACT; exon 2: GGGTT GGAAGTGTCTCATGC and TCCCACAGGTCTCTGCTAGG; exon 3: CAGTCAGATCCTAGCGTCGAG and AGCCCAACCCTTGTCCT TAC; exon 4: CCTCTGACTGCTCTTTTCACC and AGAAATGCAG GGGGATACG; exon 9: GCAGTTATGCCTCAGATTCACT and AA CTTTCCACTTGATAAGAGGTC; exon 10: GTACTGTGAATATAC TTACTTCT and CCTATGGCTTTCCAACCTAGGAA; exon 11: TTA GGCCCTTCAAAGCATTGGT0 and CACCTATTGCAAGCAAGG GTTCA.

\section{Microarray analysis}

The expression profile of the same panel of 30 colorectal cancer cell lines was assessed in using 9216-sequence cDNA microarrays from the Albert Einstein Cancer Center Facility as previously described (Mariadason et al, 2003). For each cell line, hybridisations were carried out in duplicate starting from RNA isolated from independent cultures. For each set of replicates, the mean expression value for each sequence was determined and entered into a final database for further analyses. The expression data for the 3725 sequences with a significant level of expression (defined as signal $>$ background plus two standard deviations in the Cy5 and/or Cy3 channel) in at least one replicate for all 30 cell lines was used in subsequent analyses. All the databases are available on our website (www.augenlichtlab.com).

\section{'Leave-One-Out' cross-validation analysis}

All leave-one-out analyses (Efron and Tibshirani, 1993) were performed using genes that showed a significant level of expression above background in each of the 30 cell lines ( 3725 of the 9216 genes on the arrays). First, from the 30 cell lines, cell line 1 was removed from consideration, leaving 29 cell lines for analysis. For these 29 cell lines, the Pearson correlation between the level of expression of each of the 3725 genes and the percentage of apoptosis induced by $10 \mu \mathrm{m}$ oxaliplatin was computed, and the $N$ genes highest absolute value correlations (i.e., corresponding to $N$ genes) were selected. $N$ was varied from the 10 to 200 bestcorrelated genes. As a control, $N$ randomly selected genes were also analysed. To reduce the number of genes to a smaller set of variables, principal components analysis (PCA) was performed. PCA enables a large number of variables to be reduced to linear combinations of variables that can be used to predict an outcome. From the PCA, the principal components (PCs) having the 10 largest eigenvalues were selected. In general, these 10 PCs accounted for approximately $60 \%$ of the variance in the selected genes. Next a multiple regression model was developed using the 10 PCs to predict apoptosis, based on the 29 cell lines in the analysis. Once the regression equation was derived, the 10 PCs corresponding to the 'left out' cell line were computed and substituted into the derived regression equation to yield a prediction of apoptosis in the left out cell line. Thus, the final results for this first leave-one-out procedure were the predicted value of apoptosis for the left out cell line $\left(y_{1}^{*}\right)$ and the observed value $\left(y_{1}\right)$.

After this first leave-one-out procedure was completed, the left out cell line was replaced in the data set, and cell line 2 was removed, once again leaving 29 cell lines in the data set with 1 cell line left out. The entire procedure was repeated for all 30 cell lines so that the final result was a set of predicted apoptosis values for each cell line that had been left out and the corresponding observed value. Each of these 30 leave-one-out procedures yielded 30 pairs of predicted and observed apoptosis values: $y_{1}^{*}, y_{1}, y_{2}^{*}, y_{2}$, $\ldots, y_{30}{ }^{*}, y_{30}$.

To determine how well a given regression model predicted observed apoptosis in the left out cell line, the natural log of observed apoptosis $\left(\ln \left(y_{\mathrm{i}}\right)\right)$ was plotted as a function of the natural $\log$ of the predicted value $\left(\ln \left(y_{\mathrm{i}}^{*}\right)\right)$, and a simple linear regression was constructed. The purpose of this regression analysis was to determine whether the predicted and observed values obeyed the equation $y_{\mathrm{i}}=y_{\mathrm{i}}^{*}$ (i.e., whether the points fall on the line of equality). If the prediction rule is true, then the observed and predicted values would be equal or nearly equal. The measure of linear fit was $r$, and the hypothesis of falling on the line of equality was tested by comparing the slope to unity and $y$ intercept to zero. 


\section{RESULTS}

Oxaliplatin induces a G2/M cell cycle arrest and apoptosis

Exposure of an asynchronous culture of HCT116 colon carcinoma cells to clinically achievable concentrations (Ehrsson et al, 2002; Tassone et al, 2002) of the platinum compound oxaliplatin resulted in a significant time- and concentration-dependent accumulation of cells in the G2/M phases of the cell cycle and a reduction of cells in $S$ phase (Figure 1A-D). These effects of oxaliplatin on cell cycle progression of proliferating HCT116 cells were accompanied by a significant proportion of cells showing signs of an apoptotic death, which was confirmed by the characteristic morphological changes observed in DAPI-stained nuclei of oxaliplatin-treated cells (Figure 2A and B). Quantification of the proportion of apoptotic cells by PI staining and flow cytometric analysis demonstrated that exposure of HCT116 cells to clinically achievable concentrations of oxaliplatin resulted in a significant time-dependent induction of apoptosis (Figures 1A and 2C) and that the proportion of apoptotic cells was concentrationdependent (Figures 1B and 2D).

The apoptotic cascade initiated by oxaliplatin is characterised by translocation of Bax to the mitochondria, cytochrome $c$ release and caspase 3 activation

To investigate the molecular cascade of events following exposure to oxaliplatin, we utilised HCT116 cells, which have a wild-type p53 gene and express a functional Bax protein. Immunofluorescent staining of Bax in untreated HCT116 cells demonstrated a diffuse cytoplasmic localisation of Bax in most cells (Figure 3A). In agreement with a low incidence $(<1 \%)$ of spontaneous apoptosis in untreated cultures (see Figure 2C), a small proportion of cells showed punctate Bax staining that was demonstrated to localise to the mitochondria by co-staining with Hsp60, a heat shock protein with mitochondrial localisation (Supplementary material Figure 1). However, exposure of HCT116 cells to $10 \mu \mathrm{M}$ oxaliplatin resulted in a significant $(P<0.001)$ increase in the number of cells that exhibited a mitochondrial pattern of Bax staining (white arrowheads in Figure 3A). Translocation of Bax to the mitochondria has been implicated in the formation of the permeability transition pore and cytochrome $c$ release from the mitochondria into the cytoplasm (Narita et al, 1998; Gross et al, 1999). Nonapoptotic untreated HCT116 cells exhibited a mitochondrial localisation of cytochrome $c$ (Figure 3A). However, oxaliplatin treatment resulted in an increase in the number of cells showing a diffuse cytoplasmic cytochrome $c$ immunostaining (yellow arrowheads in Figure 3A). The observed relocalisation of Bax and cytochrome $c$ following treatment of HCT116 cells with oxaliplatin was concurrent (Figure $3 \mathrm{~A}$ ) and time- and concentration-dependent (Figure 3B and C). Extension of these analyses to other colorectal cancer cell lines showed that exposure of RKO, RW2982 and SW403 cells to 10,20 or $50 \mu \mathrm{M}$ oxaliplatin resulted in a significant $(P<0.01)$ increase in the number of cells showing Bax/cytochrome $c$ re-localisation (Figure 3C).

Cytoplasmic cytochrome $c$ has been shown to bind to other components of the apoptosome, resulting in caspase activation (Liu et al, 1996; Zou et al, 1997). A time-dependent Caspase 3 activation was demonstrated in oxaliplatin-treated cells by immunostaining with a fluorescently labelled antibody that binds specifically to active Caspase 3 , and quantified using flow cytometry (Figure 4A). In agreement with this observation, treatment of HCT116 cells with oxaliplatin in the presence of different concentrations of $\mathrm{z}$-VAD-fmk, a pan-caspase inhibitor, reduced oxaliplatin-induced apoptosis in a concentration-dependent manner (Figure 4B).

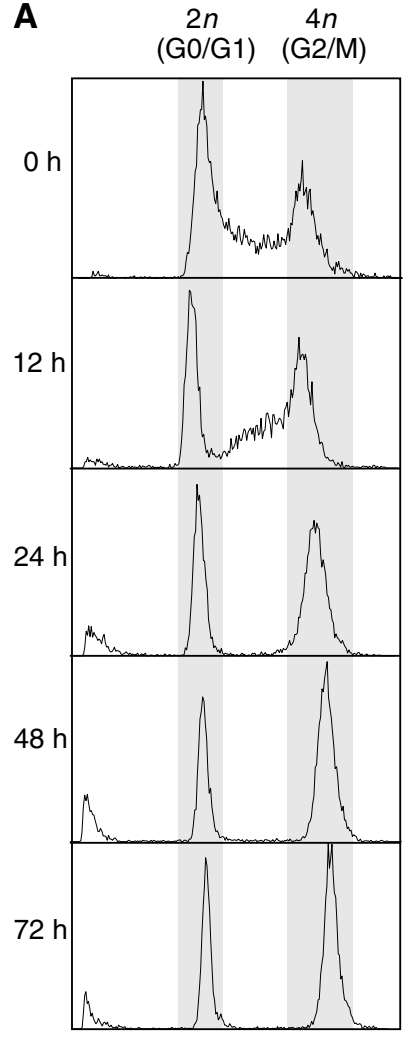

DNA content

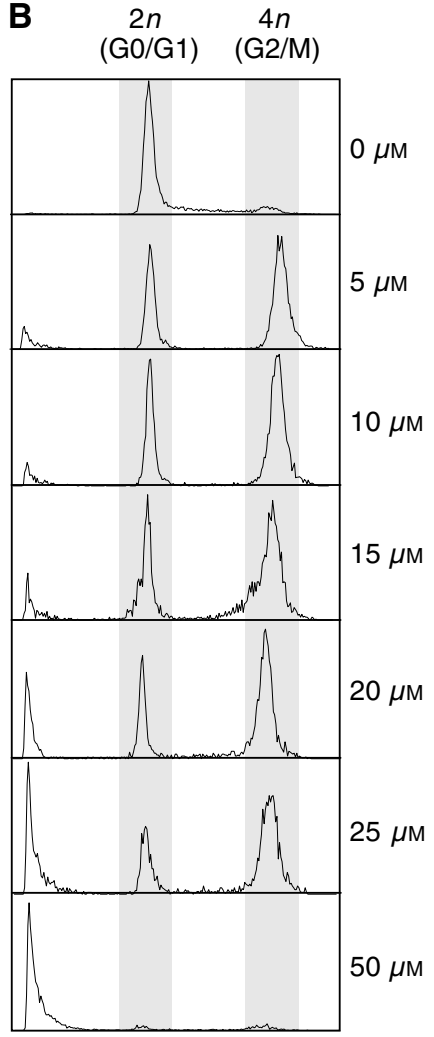

DNA content
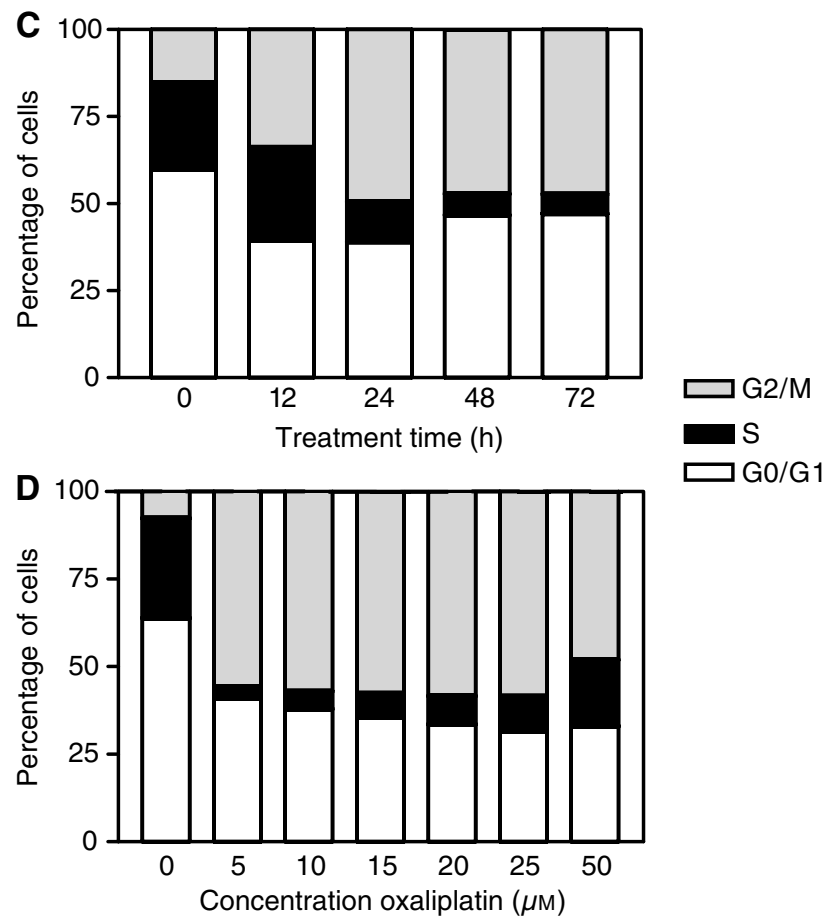

Figure I Effects of oxaliplatin on cell cycle. The cell cycle distribution of HCTI I 6 cells was determined after, (A) exposure to $5 \mu$ M oxaliplatin for different times, and (B) treatment for $72 \mathrm{~h}$ with different concentrations of oxaliplatin. Representative experiments are shown. In panels $(\mathbf{C}$ and $\mathbf{D})$ the number of cells in G0/GI, S phase and G2/M were quantified by PI staining and flow cytometric analysis. Mean of three experiments is shown. 

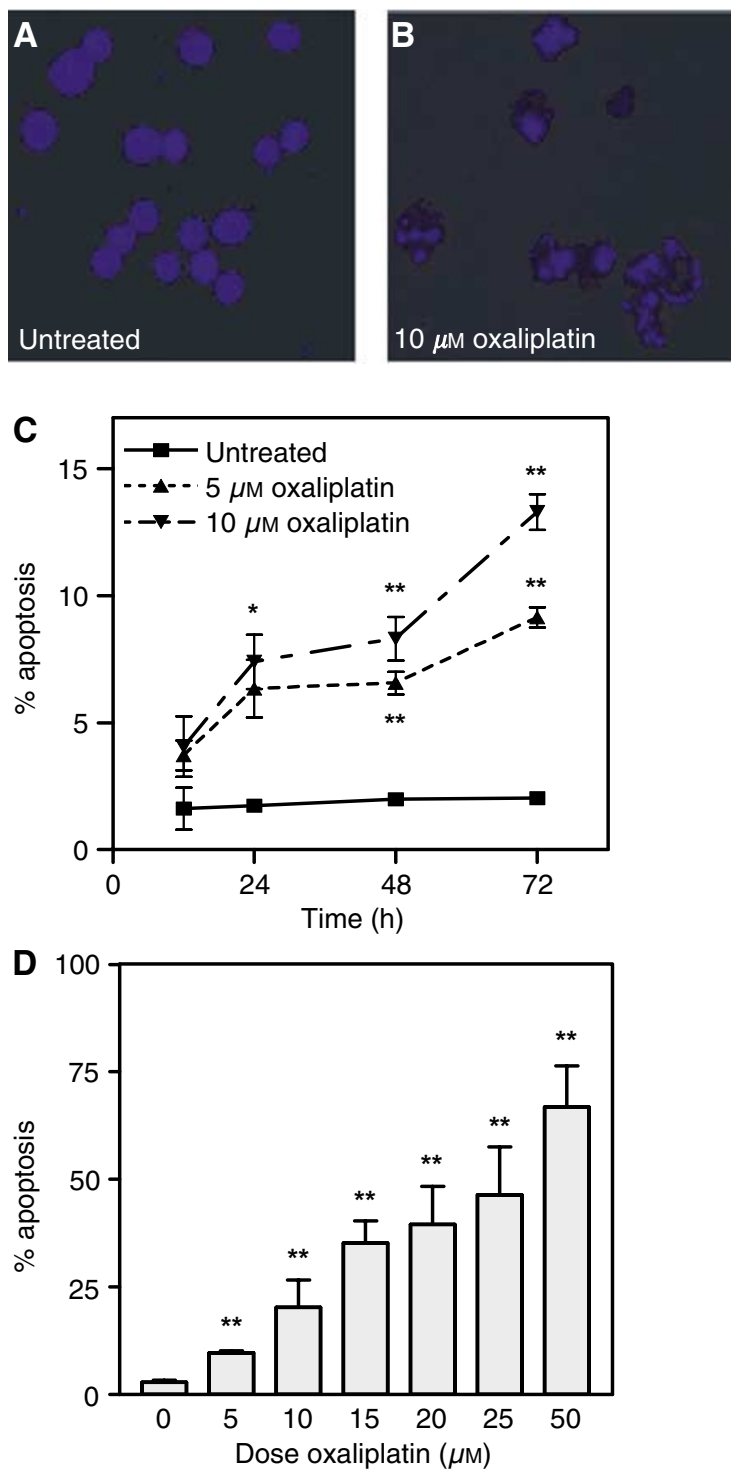

Figure 2 Induction of apoptosis by oxaliplatin. (A) Nuclear morphology of DAPI stained untreated HCTI I 6 cells and $(\mathbf{B})$ floating cells from cultures treated with $10 \mu \mathrm{M}$ oxaliplatin for $48 \mathrm{~h}$. The number of apoptotic cells was quantified by PI staining and flow cytometric analysis in cultures treated with 5 or $10 \mu \mathrm{M}$ oxaliplatin for different times (C) and with different concentrations after $72 \mathrm{~h}$ of treatment (D). Mean of three experiments \pm s.e. of the mean is shown in $(\mathbf{C}$ and $\mathbf{D}) .{ }^{*} P<0.05$ and ${ }^{*} * P<0.005$ (Student's t-test).

\section{Targeted inactivation of Bax decreased the apoptotic response to oxaliplatin}

The cellular translocation of Bax to the mitochondria observed in HCT116 cells following exposure to oxaliplatin suggested a functional role for this $\mathrm{Bcl} 2$ family member in the apoptotic cascade initiated by oxaliplatin. To investigate the role of Bax in oxaliplatin-induced apoptosis, we utilised an isogenic HCT116 derivative line that differs only in the absence of a functional Bax gene. Propidium iodide (PI) staining and flow cytometric analysis demonstrated a significant $(P<0.03)$ time- and dose-dependent reduction in the number of apoptotic cells in HCT116 $\mathrm{Bax}^{-/-}$cells compared to isogenic $\mathrm{Bax}^{+/+}$cells following oxaliplatin exposure (Figure 5A and B). In agreement with this observation, HCT116 $\mathrm{Bax}^{-l-}$ cells treated with $20 \mu \mathrm{M}$ oxaliplatin for $24 \mathrm{~h}$ showed a significant $(P=0.03)$ reduction compared to isogenic $\mathrm{Bax}^{+/+}$cells in the number of cells with the cytosolic staining pattern of cytochrome $c$ characteristic of apoptotic cells (Figure 5C), further demonstrating an important functional role of Bax in oxaliplatininduced apoptosis.

Oxaliplatin-induced apoptosis is not dependent upon Fas/ FasL association in HCT116 cells

Bax relocalisation to the mitochondria, accumulation of cytochrome $c$ in the cytoplasm and Caspase 3 activation are all events consistent with an intrinsic pathway of activation of apoptosis by oxaliplatin. To investigate the contribution of the extrinsic pathway in oxaliplatin-induced apoptosis, we used antibodies that specifically recognise either the Fas receptor (ZB4) or the Fas ligand (NOK-1) and disrupt Fas/FasL association and the subsequent induction of apoptosis by this pathway. Preincubation of HCT116 cells with either ZB4 or NOK-1 antibodies was effective in preventing apoptosis induced by recombinant human soluble Fas ligand (rhFasL; Figure 6A). However, pretreatment with ZB4 or NOK-1 antibodies did not affect apoptosis induced by oxaliplatin (Figure 6A), suggesting that this extrinsic pathway of induction of apoptosis was not activated by oxaliplatin in HCT116 cells.

\section{Role of p53 in the response to oxaliplatin}

More than $50 \%$ of colonic tumours have a mutant p53 gene (Baker et $a l, 1990)$, and a functional p53 protein has been shown to be important for the cellular response to a variety of proapoptotic stimuli, including chemotherapeutic agents commonly used in the treatment of colorectal cancer, such as 5FU and CPT-11 (Bunz et al, 1999; Arango et al, 2001, 2003; Magrini et al, 2002). Here, we demonstrate that exposure of wild-type p53 HCT116 cells to oxaliplatin results in increased levels of p53 (Figure 6B), and consistent with this observation, the p53 target gene $\mathrm{p} 21^{\text {wafl/cip } 1}$ was also upregulated (Figure 6B). The product of the p53 gene is a transcription factor that can either promote apoptosis, through different mechanisms such as Bax upregulation, or induce cell cycle arrest and DNA damage repair by means of the transcriptional upregulation of genes such as $\mathrm{p} 21^{\text {waf1/cip } 1}$ and Gadd45. Therefore, we directly tested the role of p53 in the sensitivity of colon cancer cells to oxaliplatin using parental wild-type p53

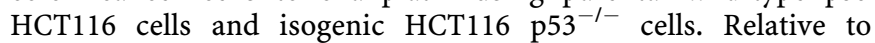
parental cells, p53-deficient HCT116 cells showed a time- and concentration-dependent protection from the apoptotic effects of oxaliplatin (Figure 7A and $\mathrm{B}$ ). The reduced apoptotic effects of oxaliplatin in HCT116 $553^{-1-}$ could be detected after $16 \mathrm{~h}$ of treatment as a 10 -fold reduction in the number of cells exhibiting Bax translocation and cytochrome $c$ release compared to parental HCT116 $53^{+/+}$(not shown). Moreover, the concentration of oxaliplatin necessary to cause a $50 \%$ growth inhibition $\left(\mathrm{GI}_{50}\right)$ after $72 \mathrm{~h}$ of exposure was four-fold higher in HCT116 $\mathrm{p} 53^{-1-}$ cells compared to parental HCT116 cells $(2.04 \pm 0.15$ and $0.53 \pm 0.04 \mu \mathrm{M}$ respectively; $P<0.0001$; Figure $7 \mathrm{C}$ ). To investigate the long-term implications of the reduced apoptosis and growth inhibition in response to oxaliplatin in HCT116 $\mathrm{p}^{-1-}$ cells, we assessed the clonogenic potential of parental HCT116 $\mathrm{p}^{+1+}$ and isogenic HCT116 p53 $3^{-1-}$ cells 2 weeks after exposure to oxaliplatin for $9 \mathrm{~h}$. This assay demonstrated that exposure of parental HCT116 $\mathrm{p} 53^{+1+}$ cells to concentrations of oxaliplatin ranging from 2.5 to $4 \mu \mathrm{M}$, resulted in up to $70 \%$ reduction in the number of cells with longterm clonogenic potential. In contrast, these concentrations of oxaliplatin had no effect on clonogenicity of HCT116 p53 ${ }^{-1-}$ cells (Figure 7D), further demonstrating that inactivation of $\mathrm{p} 53$ in colon cancer cells results in a significant protection from oxaliplatin cytotoxicity.

To further investigate the role of p53 in the response of colorectal cancer cells to oxaliplatin, we assessed the sensitivity to 

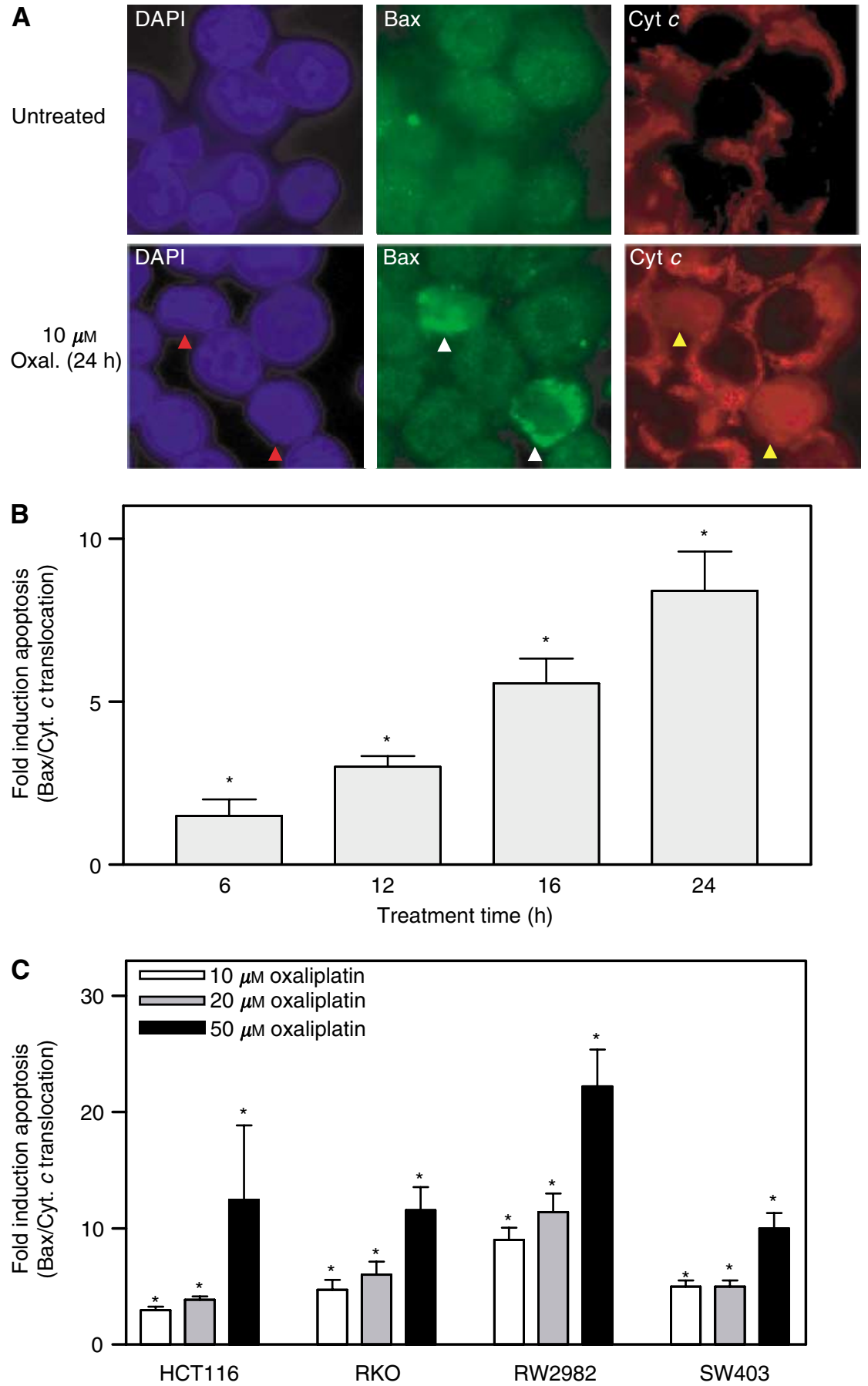

Figure 3 Oxaliplatin induced apoptosis is characterised by Bax relocalisation and cytochrome c release. (A) Immunofluorescent staining with a Bax antibody demonstrating diffuse cytoplasmic staining in the majority of the cells in untreated cultures is shown. Exposure to $10 \mu \mathrm{M}$ oxaliplatin for $24 \mathrm{~h}$ resulted in a significant proportion of cells exhibiting punctate Bax staining (white arrowheads) consistent with its mitochondrial localisation (see Results). Cytochrome $\mathrm{c}$ was confined to the mitochondria in the majority of untreated cells. Oxaliplatin treatment resulted in a significant increase in the number of cells displaying a diffuse cytosolic staining of cytochrome $c$ (yellow arrowheads). (B) Fold induction in the number of cells exhibiting simultaneous Bax relocalisation and cytochrome $\mathrm{c}$ release in cultures treated with $50 \mu \mathrm{M}$ oxaliplatin for various times (mean of at least two experiments \pm s.e.). (C) Treatment of HCTI I6, RKO, RW2982 and SW403 cells with different concentrations of oxaliplatin for $24 \mathrm{~h}$ resulted in a significant concentration-dependent increase in the number of cells showing Bax and cytochrome $c$ re-localisation. $* P<0.01$ (Student's $t$-test).

this agent in a panel of 30 different colorectal cancer cell lines of known p53 mutational status (Mariadason et al, 2003). Of these 30 cell lines, 11 had a wild-type p53 gene, and the remaining 19 exhibited inactivating mutations in this tumour suppressor. Considerable variability was observed among different colorectal cancer cell lines in the number of apoptotic cells following $72 \mathrm{~h}$ treatment with $10 \mu \mathrm{m}$ oxaliplatin (Figure $8 \mathrm{~A}$ ). Despite the clear role of 553 in the apoptotic response to oxaliplatin demonstrated using the HCT116 isogenic system that differs only in the presence or absence of a functional p53 protein, the mutational status of this 


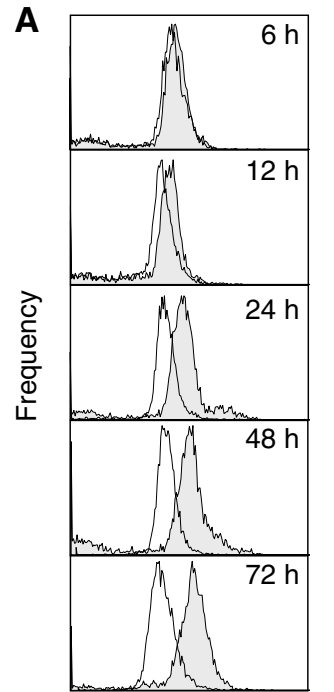

FL2-H

Untreated

$\square 25 \mu \mathrm{m}$ Oxal.

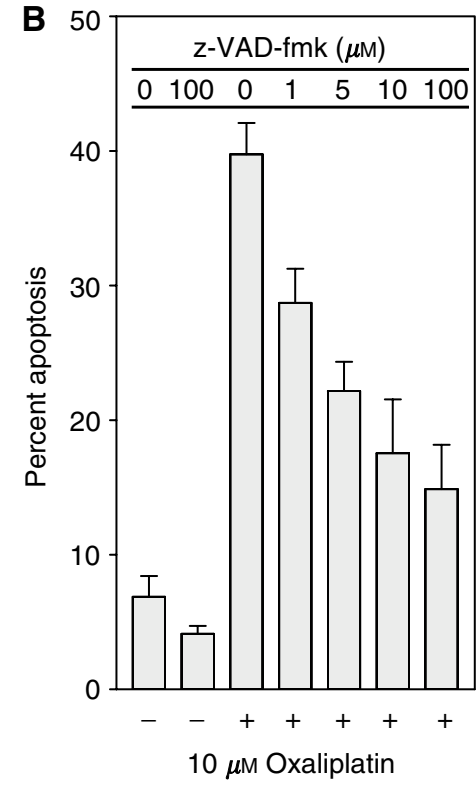

Figure 4 Caspase 3 activation in oxaliplatin treated cells. (A) FACS analysis of HCTI 16 cells stained with a PE-conjugated antibody specific to active Caspase 3 demonstrates that oxaliplatin treatment induces a timedependent increase of active Caspase 3. (B) Oxaliplatin-induced apoptosis was abrogated in a dose-dependent manner by the caspase inhibitor zVAD-fmk. Mean of three experiments \pm s.e. of the mean.

tumour suppressor gene could not predict the apoptotic response to $10 \mu \mathrm{M}$ oxaliplatin (Figure $8 \mathrm{~A}$ ), suggesting that additional factors modulate sensitivity to this agent.

\section{Response to oxaliplatin can be predicted using the expression profile of untreated colorectal cancer cells}

Due to the great complexity of the molecular mechanisms determining response to oxaliplatin, analysis of the p53 mutational status is likely to be of limited predictive value in the clinical setting. As an alternative approach, we used cDNA microarray analysis to assess the levels of expression of 9216 sequences in the same panel of 30 colorectal cancer cell lines, and used the expression profile of untreated cells to make predictions concerning response to oxaliplatin.

In order to validate the accuracy of the predictions within the panel of 30 cell lines we used a 'leave-one-out' cross-validation approach. Here, one of the 30 samples is held out, and the $N$ genes whose expression best correlates with the apoptotic response are selected using the remaining 29 cell lines. The apoptotic response in the 30th line is then estimated using the expression of those $N$ genes and a predictor based on a multiple regression model (see Materials and Methods for details). This process is repeated 30 times holding out a different cell line in each iteration. In this way, a predicted value for the apoptotic response to oxaliplatin is obtained for each of the 30 cell lines, which can then be compared to the experimentally observed response to this agent. To optimise the predictive rule, we tested the effect of varying the number of $N$ input genes from the 10-best through 200-best correlated with oxaliplatin-induced apoptosis (see Materials and Methods). This analysis demonstrated that selection of the 80 genes best correlated with oxaliplatin-induced apoptosis produced the most accurate prediction, with a highly significant correlation $(r=0.53$, $P=0.002$ ) between the observed and estimated response to
A

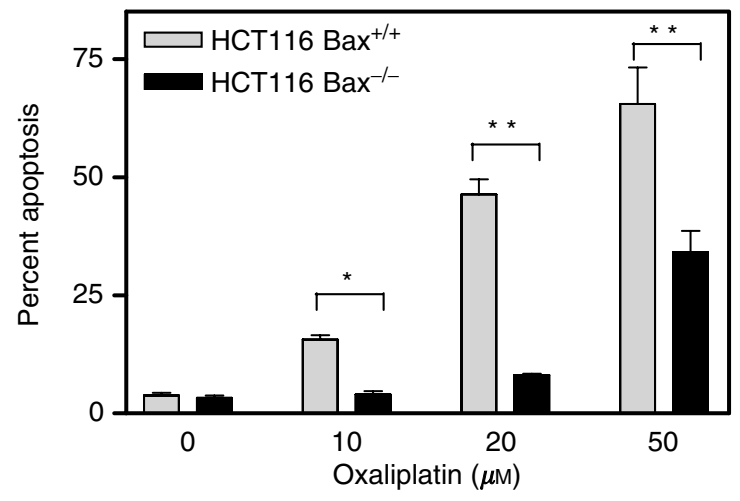

B
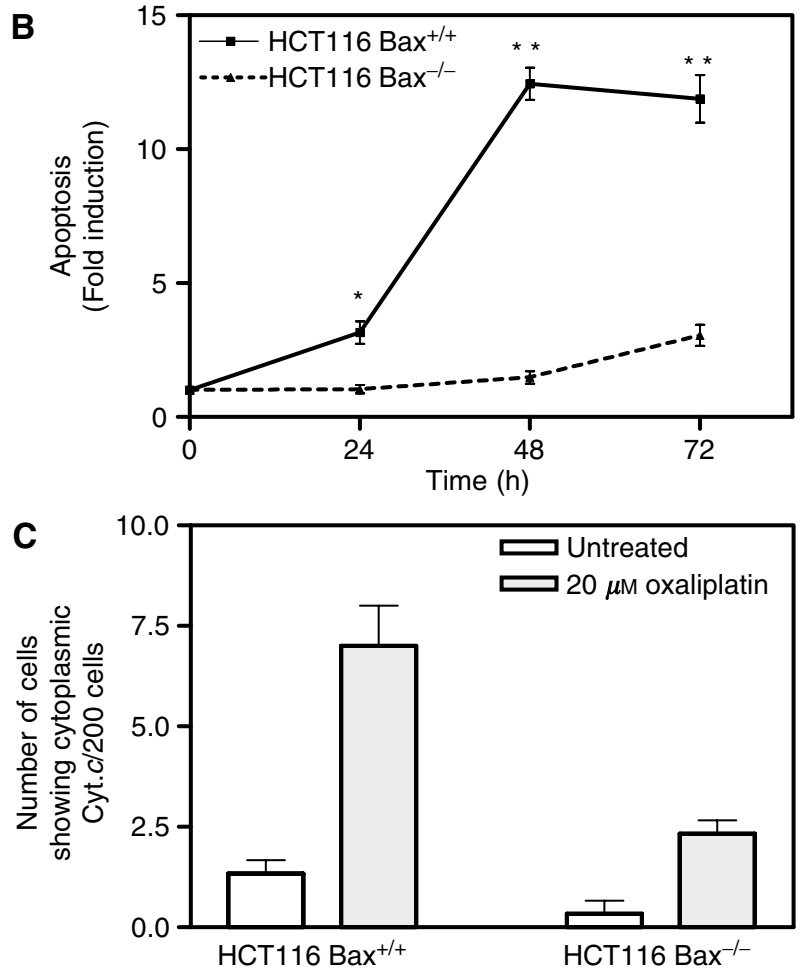

Figure 5 Role of Bax in sensitivity of colon cancer cells to oxaliplatin. (A) Percentage of apoptotic cells following exposure of HCTII6 Bax ${ }^{+1+}$ and $\mathrm{Bax}^{-1-}$ to the indicated concentrations of oxaliplatin for $72 \mathrm{~h}$ is shown. (B) Induction of apoptosis in isogenic Bax proficient and deficient HCTI I 6 cells after exposure to $20 \mu \mathrm{M}$ oxaliplatin at various times is shown. (C) Number of cells with a cytoplasmic cytochrome $c$ staining pattern (per 200 cells) following exposure to $20 \mu \mathrm{M}$ oxaliplatin for $24 \mathrm{~h}$. In all cases, the mean of three experiments \pm s.e. of the mean is shown. $* P<0.05$; $* * P<0.0$ I (Student's t-test).

oxaliplatin (Figure 8B). Importantly, the correlation between observed and estimated response to oxaliplatin by a group of 80 randomly selected genes was not significant $(P=0.19)$. This formally demonstrates that cDNA microarray based expression profiling can be used to predict response to oxaliplatin in colorectal cancer cells.

The 'leave-one-out' cross-validation approach adopted produced a slightly different list of 80 genes in each iteration, as a different cell line is held out in each round of analysis. A total of 254 genes were used in at least one of the 30 cycles, and 28 of them were present in all of the 30 gene lists used (Table 1). The expression profile of all 9216 genes in the cDNA microarrays used can be found on our website (www.augenlichtlab.com). 


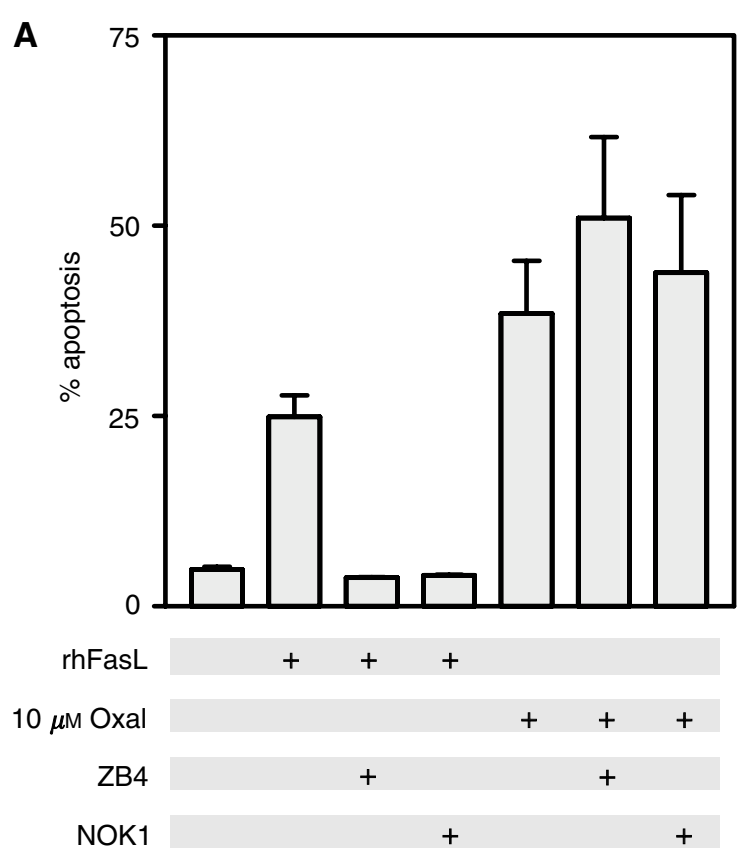

B $10 \mu \mathrm{M}$ oxaliplatin (h)

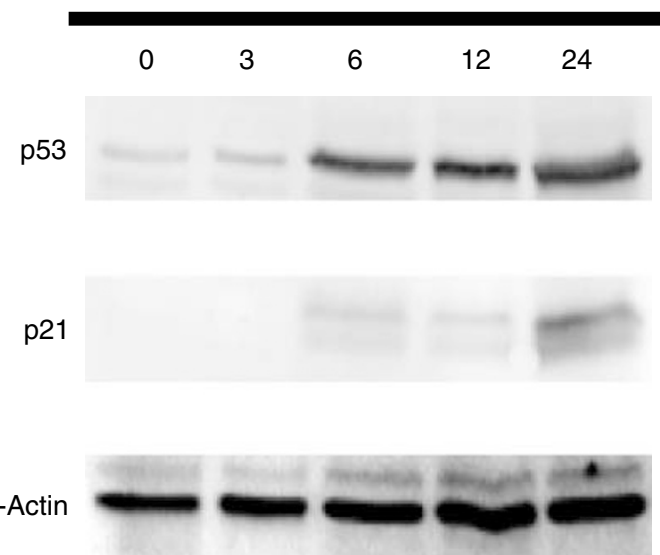

Figure 6 (A) Role of Fas/FasL association in oxaliplatin-induced apoptosis. Exposure of HCTII 6 to either recombinant human Fas ligand (rhFasL) or oxaliplatin resulted in significant induction of apoptosis. Preincubation with antibodies that prevent Fas/FasL association (ZB4 or NOK-I) for I h prevented apoptosis induced by rhFasL but had no effects on oxaliplatin-induced apoptosis. Mean of three experiments \pm s.e. (B) Effects of oxaliplatin treatment in p53 levels. Western blot analysis demonstrated that exposure of HCTI I 6 cells to $10 \mu \mathrm{M}$ oxaliplatin results in increased levels of p53 and the cdk inhibitor p2 I wafl/cip I a p53 target gene. $\beta$-Actin levels on a parallel blot are shown as a loading control.

\section{DISCUSSION}

The platinum compound oxaliplatin is frequently used in the treatment of colorectal cancer patients that are resistant to $5 \mathrm{FU}$, and can also be used in combination with 5FU or CPT-11, improving response rates and progression-free survival (Levi et al, 1993; Bertheault-Cvitkovic et al, 1996; Machover et al, 1996; de Gramont et al, 1997, 2000; Andre et al, 1999; Maindrault-Goebel et al, 1999; Giacchetti et al, 2000). Oxaliplatin disrupts DNA replication and transcription by forming intrastrand DNA adducts, but the downstream molecular events underlying the cytotoxic effects of this chemotherapeutic agent have not been well characterised.
Here, we show that exposure of HCT116 colon cancer cells to clinically relevant concentrations of oxaliplatin (Ehrsson et al, 2002; Tassone et al, 2002) greatly reduced the long-term clonogenic potential of these cells (solid line in Figure 7D). This was associated with an arrest of proliferating cells in the G2/M phases of the cell cycle (Figure 1). Consistent with this observation, there was a significant reduction in the growth rate of oxaliplatintreated cells compared to control untreated cells (solid line in Figure 7C). Importantly, exposure of HCT116 cells to oxaliplatin resulted in a significant induction of apoptosis detectable as early as $24 \mathrm{~h}$ after treatment with the lowest concentration assessed (see Figure 2C). Although impairment of the growth of tumour cells is an important component contributing to the overall response to chemotherapy, cell death is the preferred method of elimination of malignant cells, since this is a terminal and irreversible mechanism. Clonal selection of tumour cells frequently results in the acquisition of mechanisms of evading apoptosis. Therefore, understanding of the molecular mechanisms involved in the induction of apoptosis after exposure to chemotherapeutic agents is important for two reasons: first, it can provide information regarding pathways that may be modulated to improve treatment efficacy, and second, it can lead to the identification of markers capable of predicting the probability of response to treatment.

In this study we demonstrate that exposure of four different colorectal cancer cells (HCT116, RKO, RW2982 and SW403) to oxaliplatin resulted in recruitment of Bax to the mitochondria, release of cytochrome $c$ to the cytosol and Caspase 3 activation. Targeted inactivation of Bax in HCT116 cells resulted in a significant reduction in the number of cells displaying a cytosolic staining pattern of cytochrome $c$ and terminal apoptosis following exposure to oxaliplatin. These results demonstrated an important functional role of Bax in the apoptotic cascade of events initiated by exposure to oxaliplatin and are in agreement with previous reports (Gourdier et al, 2002; Hayward et al, 2004). Moreover, it has been suggested that frameshift mutations in the G8 track of the Bax gene could contribute to the acquisition of resistance to oxaliplatin in HCT116 cells (Gourdier et al., 2002). Collectively, these observations suggest the potential of Bax as a genetic marker capable of predicting the probability of response of colorectal cancer patients to this important chemotherapeutic agent.

Bax relocalisation to the mitochondria, release of cytochrome $c$ to the cytosol and Caspase 3 activation, are all events consistent with the induction of an intrinsic apoptotic pathway, characterised by the central role of the mitochondria in the initiation of the caspase cascade. Some chemotherapeutic agents, however, induce an apoptotic response through activation of the extrinsic pathway by promoting Fas receptor/Fas ligand association, which in turn leads to the formation of the death-inducing signaling complex (DISC) and the autocatalytic activation of pro-caspase 8 . To investigate the contribution of this pathway to oxaliplatin-induced apoptosis, we utilised antibodies that bind to Fas or FasL, thus preventing the association of these two proteins. Although abrogation of Fas/FasL association completely prevented apoptosis induced by recombinant human Fas ligand, it had no effect on oxaliplatin-induced apoptosis, suggesting the predominance of the intrinsic pathway in the apoptotic program initiated by oxaliplatin exposure in HCT116. However, Marchetti et al (2004) have recently demonstrated the involvement of the extrinsic pathway in oxaliplatin-induced apoptosis in HCT15 colon cancer cells, suggesting that the role of this pathway may be tumour dependent.

Considerable progress has been made in the identification of genetic markers allowing prediction of colorectal cancer response to 5-FU and CPT-11, which together with oxaliplatin are commonly used for the treatment of these patients (Augenlicht et al, 1997; Bunz et al, 1999; Salonga et al, 2000; Arango and Augenlicht, 2001; Arango et al, 2001, 2003). However, despite recent efforts (Arnould et al, 2003; Rakitina et al, 2003) it is currently not possible to accurately predict response to oxaliplatin. 

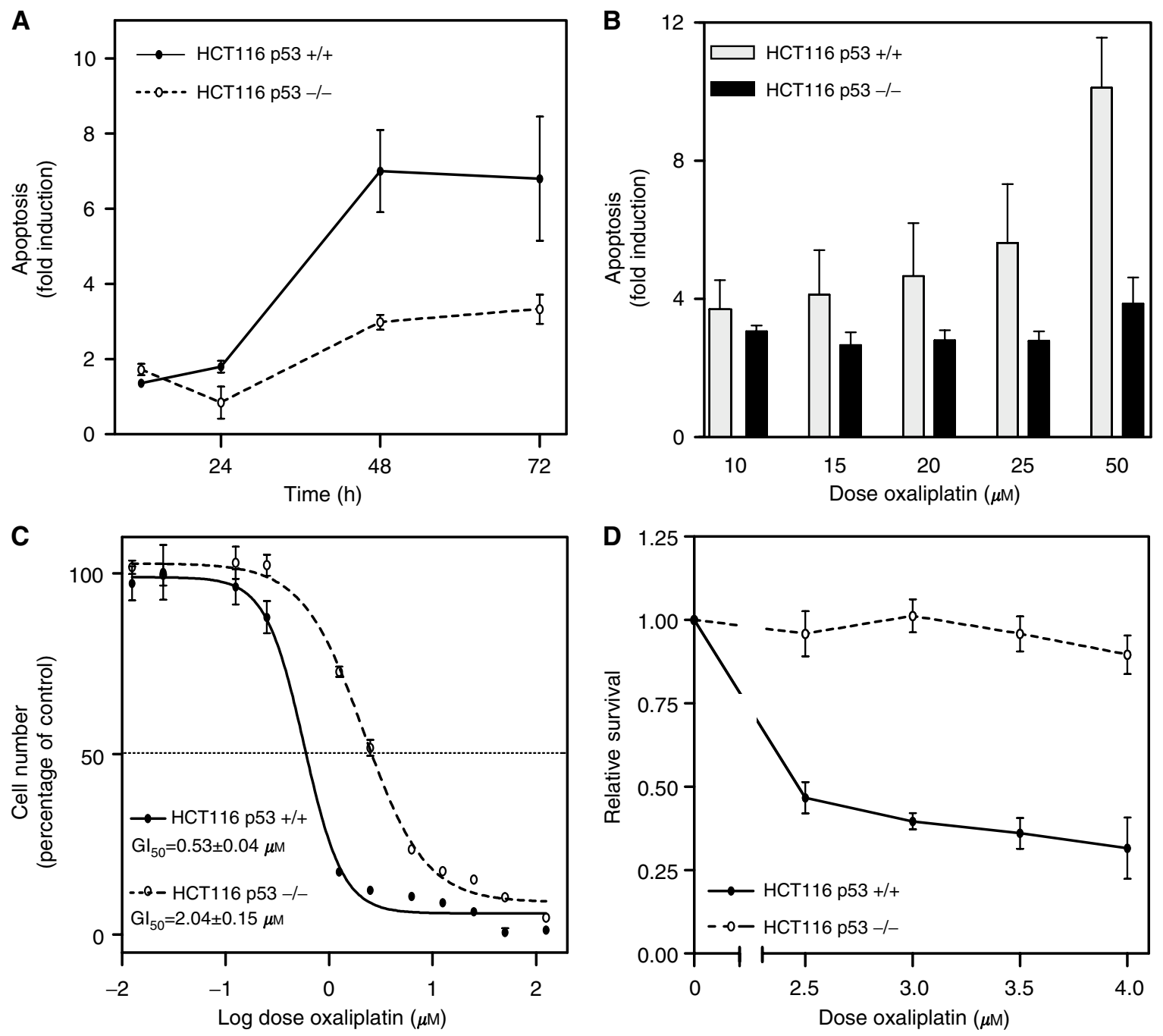

Figure 7 Role of p53 in sensitivity of colon cancer cells to oxaliplatin. (A) Fold induction of apoptosis in HCTII6 p53 $3^{+/+}$and HCTII6 p53 $3^{-1-}$ cultures after exposure to $25 \mu \mathrm{M}$ oxaliplatin for different times, or (B) to different concentrations oxaliplatin for $72 \mathrm{~h}$ are shown. (C) Comparison of oxaliplatininduced growth inhibition between HCTI $16 \mathrm{p} 53^{+/+}$and $\mathrm{p} 53^{-1-}$ cells. (D) Clonogenic potential of HCTII 6 p53 $3^{+1+}$ and $\mathrm{p} 53^{-1-}$ cells treated with $2.5-$ $4 \mu \mathrm{M}$ oxaliplatin for $9 \mathrm{~h}$. Values shown are the mean of at least three different experiments \pm s.e. of the mean.

p53 is mutated in over $50 \%$ of colorectal tumours, and the mutational status of this tumour suppressor has been shown to increase or decrease tumour sensitivity to a number of chemotherapeutic agents. Here we show that oxaliplatin-induced apoptosis was associated with upregulation of $\mathrm{p} 53$ protein levels, detectable within $6 \mathrm{~h}$ of treatment. This suggested a role of p53 in the apoptotic cascade initiated by oxaliplatin. Using an isogenic system we showed that targeted inactivation of p53 resulted in a four-fold increase in the $\mathrm{GI}_{50}$, reduced apoptosis and induced a significant increase in clonogenic potential after exposure to oxaliplatin, demonstrating that inactivation of p53 can lead to significantly increased resistance to oxaliplatin.

However, there are some reports showing that p53 inactivation does not lead to increased resistance to oxaliplatin (Seo et al, 2002; Petit et al, 2003), suggesting that the role of p53 in the cellular response to oxaliplatin may be tumour dependent. To further investigate the role of $\mathrm{p} 53$ in sensitivity of colorectal cancer cells to oxaliplatin, we used a panel of 30 different cell lines of known p53 mutational status. We measured the induction of apoptosis following exposure of these 30 cell lines to clinically achievable doses of oxaliplatin, and found that cell lines with a wild type and mutant p53 gene did not significantly differ in their apoptotic response to oxaliplatin (see Figure $8 \mathrm{~A}$ ). Similar disparities have been reported for the role of $\mathrm{p} 53$ in $5 \mathrm{FU}$ response, depending upon whether isogenic cell lines or panels of colorectal cell lines were studied (Yang et al, 1996; Bunz et al, 1999; Violette et al, 2002). Therefore, despite the clear role of p53 in the response of colon cancer cells to oxaliplatin demonstrated using the HCT116 isogenic system, the multiple genetic and epigenetic differences that exist between tumours are likely to affect numerous pathways, thus modulating sensitivity to oxaliplatin. This could limit the clinical value of p53 and other single markers of response to treatment.

Simultaneous analysis of several independent markers predicting response to drug treatment has been shown to be advantageous over single markers (Salonga et al, 2000; Arango et al, 2001). Microarray analysis provides the means of assessing the levels of expression of thousands of genes simultaneously, and we and others have recently demonstrated that the expression profile of untreated tumour cells can be used to predict response of tumour cells to different chemotherapeutic agents in vitro and in vivo (Scherf et al, 2000; Kihara et al, 2001; Zembutsu et al, 2002; Mariadason et al, 2003). Here, we used a cDNA microarray-based 

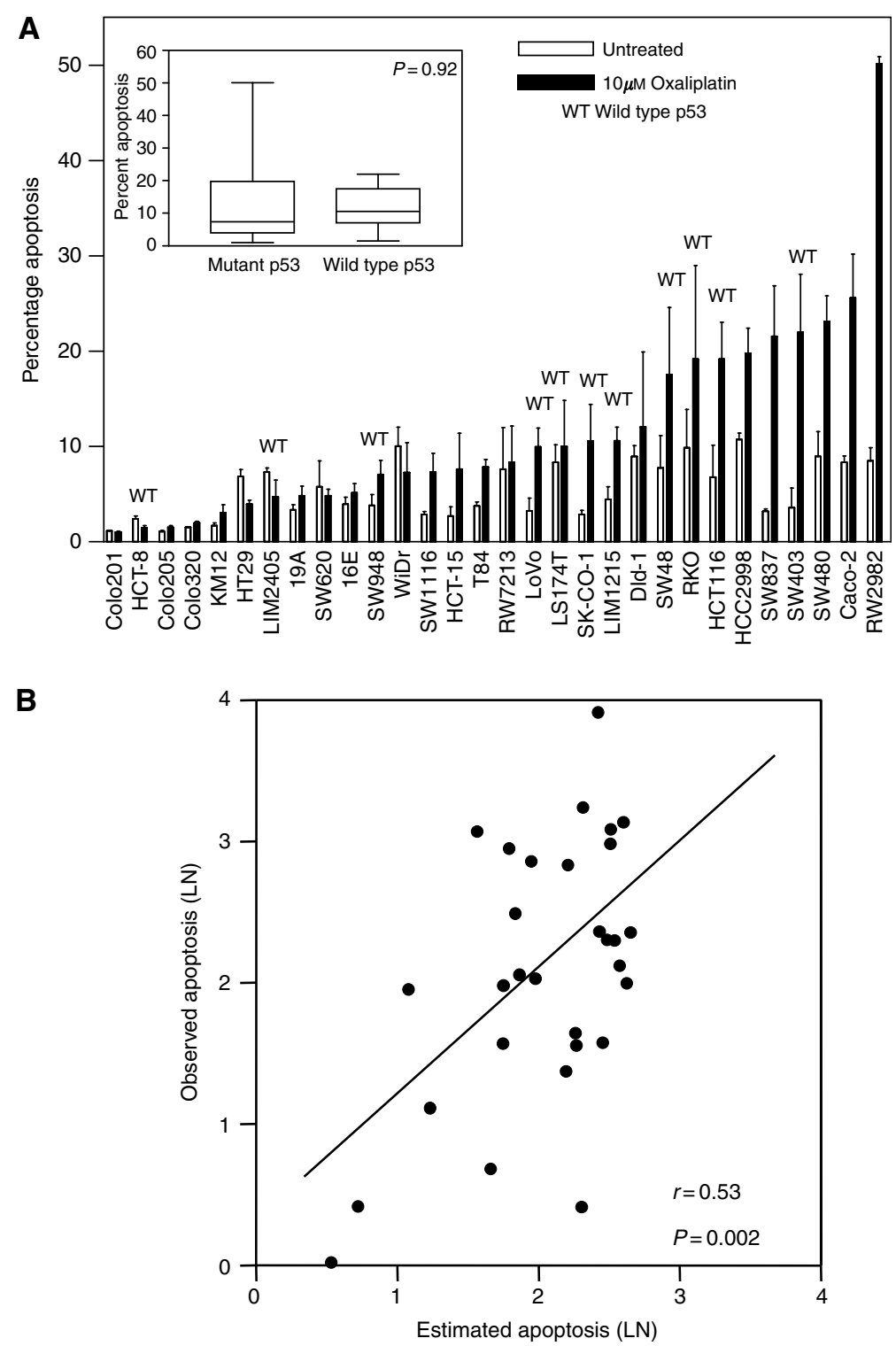

Figure 8 Microarray-based prediction of response to oxaliplatin. (A) Percentage of apoptotic cells following exposure of a panel of 30 colorectal cancer cell lines to $10 \mu \mathrm{M}$ oxaliplatin for $72 \mathrm{~h}$. Cell lines with a wild-type p53 gene are indicated (WT). The inset shows the mean percentage apoptosis in p53 wild type and mutant cell lines. Mean of three independent experiments in triplicate \pm s.e. of the mean is shown. (B) Correlation between experimentally observed and expression profile predicted percentage apoptosis following treatment with $10 \mu \mathrm{M}$ oxaliplatin for $72 \mathrm{~h}$. The predicted apoptosis value for all 30 cell lines was calculated using the expression profile of the 80 genes best correlated with drug response and a multiple regression model through a leaveone-out cross-validation approach (see Material and Methods).

approach to measure the expression levels of 9216 transcripts in a panel of 30 colorectal cancer cell lines for which the sensitivity to oxaliplatin was also assessed. The profile of expression of the 80 genes best correlated with sensitivity was used to predict the quantitative apoptotic response to oxaliplatin in these 30 cell lines. Using a 'leave-one-out' cross-validation approach we demonstrated a highly significant correlation between experimentally observed and microarray-predicted apoptotic response to oxaliplatin $(R=0.53, P=0.002)$.

Our microarray experiments identified a number of genes and expressed sequence tags (ESTs) that are differentially expressed in cell lines that are sensitive and resistant to oxaliplatin. Among the 254 transcripts that were used in at least one of the 30 'leave-oneout' cross-validation loops, several of them have a known role in apoptosis (Table 1). The serine/threonine kinase Protein Kinase C alpha $(\mathrm{PKC} \alpha)$ has been associated with cell survival and the suppression of apoptosis (Deacon et al, 1997; Orlandi et al, 2003). $\operatorname{PKC} \alpha$ was represented twice in our cDNA microarray and both probes demonstrated that expression levels were lower in cell lines with a higher apoptotic response to oxaliplatin. This is in good agreement with previous reports demonstrating that $\mathrm{PKC} \alpha$ levels modulate the cellular response to cisplatin and oxaliplatin (Johnson et al, 2002; Orlandi et al, 2003). The transcription factor $\mathrm{NF} \kappa \mathrm{B}$ has been shown to be frequently deregulated in colorectal tumours, and it is associated with increased proliferation and resistance to apoptosis induced by chemotherapeutic agents (Garg and Aggarwal, 2002; Orlowski and Baldwin, 2002). Here we found that the $\mathrm{NF} \kappa \mathrm{B}$ inhibitor epsilon (NFKBIE) is expressed at higher levels in the more sensitive cell lines. This is consistent with a recent report showing that donwregulation of the transcriptional 
Table I List of 254 genes used at least once in the 30 leave-one-out cross-validation loops

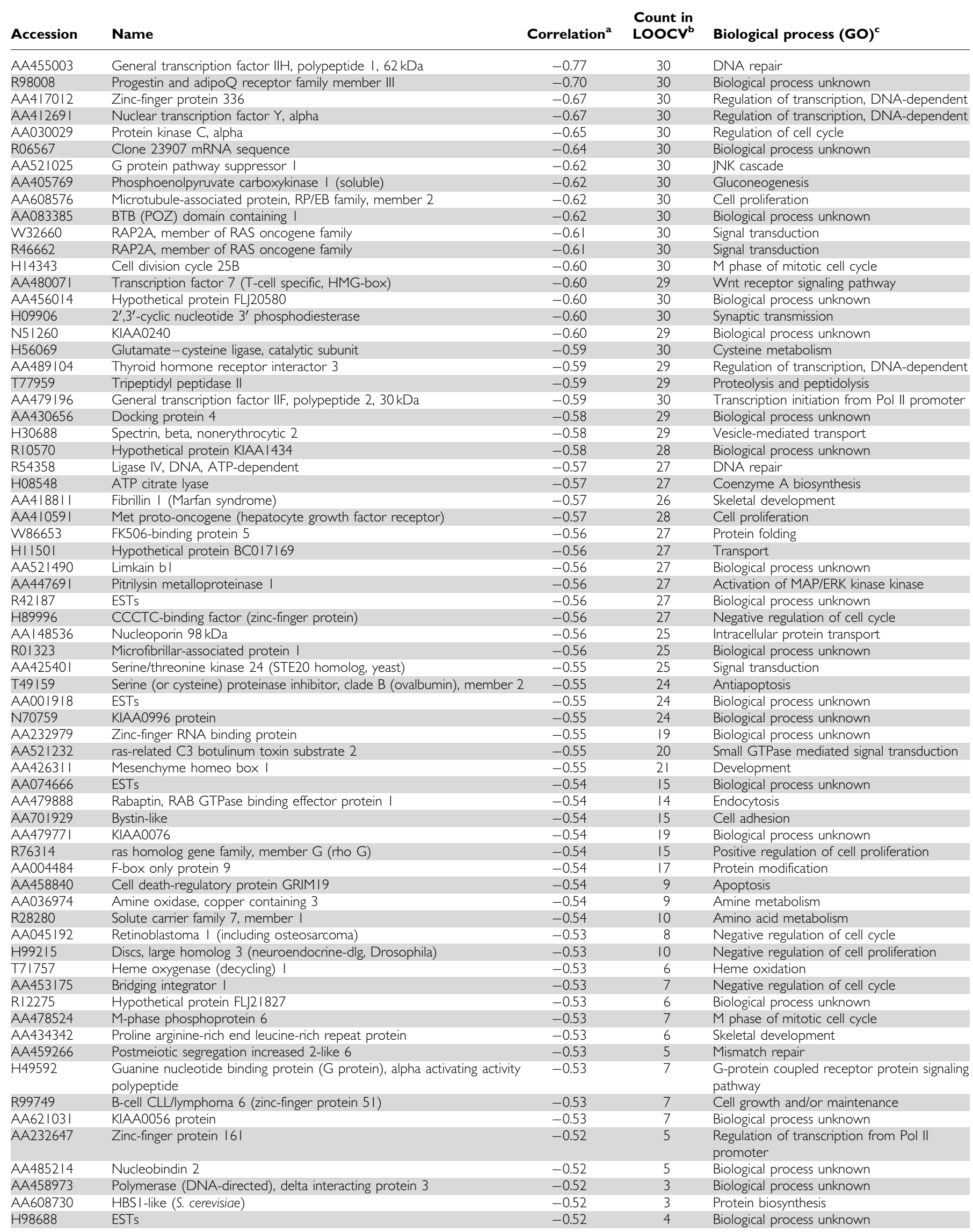


Table I (Continued)

\begin{tabular}{|c|c|c|c|c|}
\hline Accession & Name & Correlation $^{\mathrm{a}}$ & $\begin{array}{l}\text { Count in } \\
\text { LOOCV }^{b}\end{array}$ & Biological process $(\mathrm{GO})^{\mathrm{c}}$ \\
\hline AA425908 & ADP-ribosylation factor interacting protein 2 (arfaptin 2) & -0.52 & 3 & Small GTPase mediated signal transduction \\
\hline AA424937 & Protein kinase C, alpha & -0.52 & 4 & Regulation of cell cycle \\
\hline AA284338 & Chromobox homolog 5 (HPI alpha homolog, Drosophila) & -0.51 & 2 & Chromatin assembly \\
\hline AA040I70 & Chemokine (C-C motif) ligand 7 & -0.51 & 3 & Antimicrobial humoral response \\
\hline AA425089 & Clock homolog (mouse) & -0.51 & 4 & Circadian rhythm \\
\hline N58136 & Similar to KIAA0393 protein & -0.51 & 2 & Biological process unknown \\
\hline W47073 & Solute carrier family 20 (phosphate transporter), member I & -0.51 & 3 & Phosphate transport \\
\hline AA703 | 87 & Solute carrier family 33 (acetyl-CoA transporter), member I & -0.51 & 4 & Transport \\
\hline W79444 & UBX domain containing 2 & -0.51 & 2 & Biological process unknown \\
\hline R35292 & Growth arrest-specific 2 like I & -0.51 & 3 & Cell cycle arrest \\
\hline AA406027 & CD5 antigen (p56-62) & -0.51 & 2 & Cell proliferation \\
\hline W06875 & Hypothetical protein MGCI48I6 & -0.51 & 2 & Biological process unknown \\
\hline R/4855 & F-box only protein 34 & -0.50 & 2 & Biological process unknown \\
\hline AA455043 & Holocarboxylase synthetase & -0.50 & 2 & Protein modification \\
\hline AA232647 & Zinc-finger protein 161 & -0.50 & 2 & $\begin{array}{l}\text { Regulation of transcription from Pol II } \\
\text { promoter }\end{array}$ \\
\hline RII490 & Translocated promoter region (to activated MET oncogene) & -0.50 & 2 & Transport \\
\hline T58/46 & HLA complex P5 & -0.50 & 2 & Defense response \\
\hline H54366 & KIAA0034 gene, complete cds & -0.50 & 2 & Biological process unknown \\
\hline AA406269 & Nuclear factor I/X (CCAAT-binding transcription factor) & -0.50 & 2 & DNA replication \\
\hline R02346 & Small nuclear ribonucleoprotein $70 \mathrm{kDa}$ polypeptide (RNP antigen) & -0.50 & I & RNA splicing \\
\hline H64850 & Clone 23612 mRNA sequence & -0.50 & 1 & Biological process unknown \\
\hline N74574 & Hypothetical protein MGC9084 & -0.49 & 3 & Biological process unknown \\
\hline N26645 & $\begin{array}{l}\text { Neurofibromin I (neurofibromatosis, von Recklinghausen disease, } \\
\text { Watson disease) }\end{array}$ & -0.49 & 2 & RAS protein signal transduction \\
\hline R26434 & Protein phosphatase I, catalytic subunit, beta isoform & -0.49 & 1 & Biological process unknown \\
\hline AA025850 & Myosin VA (heavy polypeptide 12, myoxin) & -0.49 & 1 & Transport \\
\hline AA485443 & Ring finger protein $4 \mathrm{I}$ & -0.48 & 1 & Biological process unknown \\
\hline AA085676 & ADP-ribosylation factor guanine nucleotide factor 6 & -0.48 & 1 & Biological process unknown \\
\hline W58032 & Frizzled-related protein & -0.48 & 1 & Wnt receptor signaling pathway \\
\hline N7I 653 & Aspartoacylase (aminoacylase 2, Canavan disease) & -0.48 & 2 & Aspartate catabolism \\
\hline AA004324 & Hypothetical protein BC007706 & -0.48 & I & Biological process unknown \\
\hline AA441935 & Achaete-scute complex-like I (Drosophila) & -0.48 & I & Cell differentiation \\
\hline R22050 & Topoisomerase (DNA) II beta (I80kD) & -0.48 & I & DNA topological change \\
\hline W31074 & Fatty-acid-Coenzyme A ligase, long-chain 3 & -0.48 & 3 & Fatty acid metabolism \\
\hline T7258I & Matrix metalloproteinase 9 & -0.48 & 3 & Collagen catabolism \\
\hline AA453105 & Histone I, H2ac & -0.48 & 1 & Nucleosome assembly \\
\hline AA988746 & WD repeat and SOCS box containing protein 2 & -0.48 & 1 & Intracellular signaling cascade \\
\hline AA495766 & Chromosome condensation I-like & -0.48 & 1 & Biological process unknown \\
\hline AA489699 & COP9 constitutive photomorphogenic homolog subunit 8 (Arabidopsis) & -0.48 & 1 & Biological process unknown \\
\hline T65902 & $\begin{array}{l}\text { Splicing factor, arginine/serine-rich I (splicing factor 2, alternate splicing } \\
\text { factor) }\end{array}$ & -0.48 & 1 & mRNA splice site selection \\
\hline AA446908 & Kinesin family member $3 C$ & -0.47 & I & Biological process unknown \\
\hline AA047812 & Origin recognition complex, subunit 2-like (yeast) & -0.47 & I & DNA replication \\
\hline AA452566 & Peroxisomal membrane protein 3, $35 \mathrm{kDa}$ (Zellweger syndrome) & -0.47 & 1 & Peroxisome organization and biogenesis \\
\hline R91948 & Pantothenate kinase 3 & -0.47 & 1 & Coenzyme A biosynthesis \\
\hline T52894 & Myosin light chain I slow a & -0.47 & 1 & Muscle development \\
\hline AA001749 & Microtubule-associated protein, RP/EB family, member I & -0.47 & i & Cell proliferation \\
\hline AA430035 & Reticulon 3 & -0.47 & I & Biological process unknown \\
\hline N79179 & $\begin{array}{l}\text { Pyruvate dehydrogenase complex, lipoyl-containing component } X \text {; E3- } \\
\text { binding protein }\end{array}$ & -0.47 & 1 & Biological process unknown \\
\hline RI39|I & T54 protein & -0.47 & I & Biological process unknown \\
\hline AA447579 & Hypothetical protein FLJI I I0I & -0.47 & I & Biological process unknown \\
\hline AA454639 & F-box only protein 9 & -0.47 & 1 & Protein modification \\
\hline
\end{tabular}


Table I (Continued)

\begin{tabular}{|c|c|c|c|c|}
\hline Accession & Name & Correlation $^{a}$ & $\begin{array}{l}\text { Count in } \\
\text { LOOCV }^{b}\end{array}$ & Biological process $(\mathrm{GO})^{\mathrm{c}}$ \\
\hline AA476460 & Protein tyrosine phosphatase, receptor-type, Z polypeptide I & -0.46 & 2 & One-carbon compound metabolism \\
\hline AAI 47642 & cDNA: FLJ21949 fis, clone HEP04922 & -0.46 & I & Biological process unknown \\
\hline N80382 & Phosphodiesterase 6D, cGMP-specific, rod, delta & -0.46 & I & Visual perception \\
\hline R88246 & Adrenergic, beta, receptor kinase I & -0.45 & I & Signal transduction \\
\hline AAI50895 & Hypothetical protein MGC26690 & -0.45 & 1 & Biological process unknown \\
\hline AA40I 429 & Dynein light chain 2 & -0.45 & 2 & Microtubule-based process \\
\hline AA434I30 & Thioredoxin reductase 2 & -0.44 & I & Response to oxygen radicals \\
\hline AA453593 & $\begin{array}{l}\mathrm{BBI}=\text { malignant cell expression-enhanced gene/tumor progression- } \\
\text { enhanced gene }\end{array}$ & -0.44 & I & Protein arginylation \\
\hline T77891 & ESTs & -0.44 & I & Biological process unknown \\
\hline N48137 & Glycophorin E & -0.44 & 1 & Biological process unknown \\
\hline AA280677 & Zinc-finger protein 258 & -0.43 & I & Development \\
\hline AA026709 & Dedicator of cytokinesis 6 & -0.43 & I & Biological process unknown \\
\hline AA487070 & Similar to CGI-55 protein (LOCI52502), mRNA & -0.43 & 1 & Biological process unknown \\
\hline AA284282 & Hypothetical protein FLJ30277 & -0.43 & I & Biological process unknown \\
\hline T57859 & Natural killer cell group 7 sequence & -0.42 & 1 & Biological process unknown \\
\hline AA44800I & TBP-like I & -0.42 & i & Regulation of transcription \\
\hline N92085 & ESTs & -0.41 & I & Biological process unknown \\
\hline AA423867 & Multimerin & -0.41 & 1 & Blood coagulation \\
\hline AA443302 & ras homolog gene family, member $\mathrm{E}$ & -0.38 & I & Small GTPase mediated signal transduction \\
\hline H5236 I & ESTs & -0.37 & I & Biological process unknown \\
\hline AA482198 & Mannose phosphate isomerase & -0.36 & I & Carbohydrate metabolism \\
\hline $\mathrm{H} 66030$ & Centrosomal protein I & -0.36 & I & Biological process unknown \\
\hline AA458472 & Major histocompatibility complex, class II, DQ beta I & -0.36 & 1 & Immune response \\
\hline AA447696 & Yippee protein & -0.35 & I & Biological process unknown \\
\hline AA005228 & ESTs & 0.39 & I & Biological process unknown \\
\hline AA0048II & ESTs & 0.39 & 1 & Biological process unknown \\
\hline R54797 & ESTs, Weakly similar to reverse transcriptase homolog & 0.39 & I & Biological process unknown \\
\hline T95930 & ESTs & 0.40 & 1 & Biological process unknown \\
\hline AA0587I3 & ESTs & 0.41 & i & Biological process unknown \\
\hline T84865 & ESTs & 0.41 & I & Biological process unknown \\
\hline N46943 & GGA binding partner & 0.41 & I & Biological process unknown \\
\hline AA677403 & Glycoprotein hormones, alpha polypeptide & 0.42 & l & Cell-cell signaling \\
\hline AA872379 & SMT3 suppressor of mif two 3 homolog I (yeast) & 0.42 & 1 & Biological process unknown \\
\hline T96870 & ESTs & 0.42 & I & Biological process unknown \\
\hline AA610111 & Hypothetical protein FLJ21868 & 0.43 & I & Biological process unknown \\
\hline AA400I2I & A-kinase anchoring protein 28 & 0.44 & I & Biological process unknown \\
\hline $\mathrm{H} 72319$ & ESTs & 0.44 & I & Biological process unknown \\
\hline $\mathrm{H} 23124$ & Olfactomedin related ER localized protein & 0.44 & 1 & Biological process unknown \\
\hline AA4475I5 & MAX dimerization protein 4 & 0.44 & 1 & Negative regulation of cell proliferation \\
\hline N629/4 & EST & 0.44 & I & Biological process unknown \\
\hline T53298 & Insulin-like growth factor binding protein 7 & 0.45 & I & Negative regulation of cell proliferation \\
\hline AA421488 & CDNA FLI26472 fis, clone KDN04506 & 0.46 & I & Biological process unknown \\
\hline H93837 & Apolipoprotein $B$ (including $\mathrm{Ag}(x)$ antigen) & 0.46 & I & Lipid transport \\
\hline N78306 & ESTs & 0.46 & l & Biological process unknown \\
\hline N32502 & ESTs & 0.46 & 1 & Biological process unknown \\
\hline AA488672 & Kruppel-like factor 7 (ubiquitous) & 0.47 & 1 & $\begin{array}{l}\text { Regulation of transcription from Pol II } \\
\text { promoter }\end{array}$ \\
\hline AA0538I5 & Hypothetical protein FLJI I 767 & 0.47 & I & Biological process unknown \\
\hline $\mathrm{R} 027 / 6$ & Hypothetical protein FLJI4639 & 0.47 & I & Biological process unknown \\
\hline AA701545 & Ribonuclease, RNase A family, k6 & 0.47 & I & RNA catabolism \\
\hline R93069 & ESTs & 0.47 & I & Biological process unknown \\
\hline
\end{tabular}


Table I (Continued)

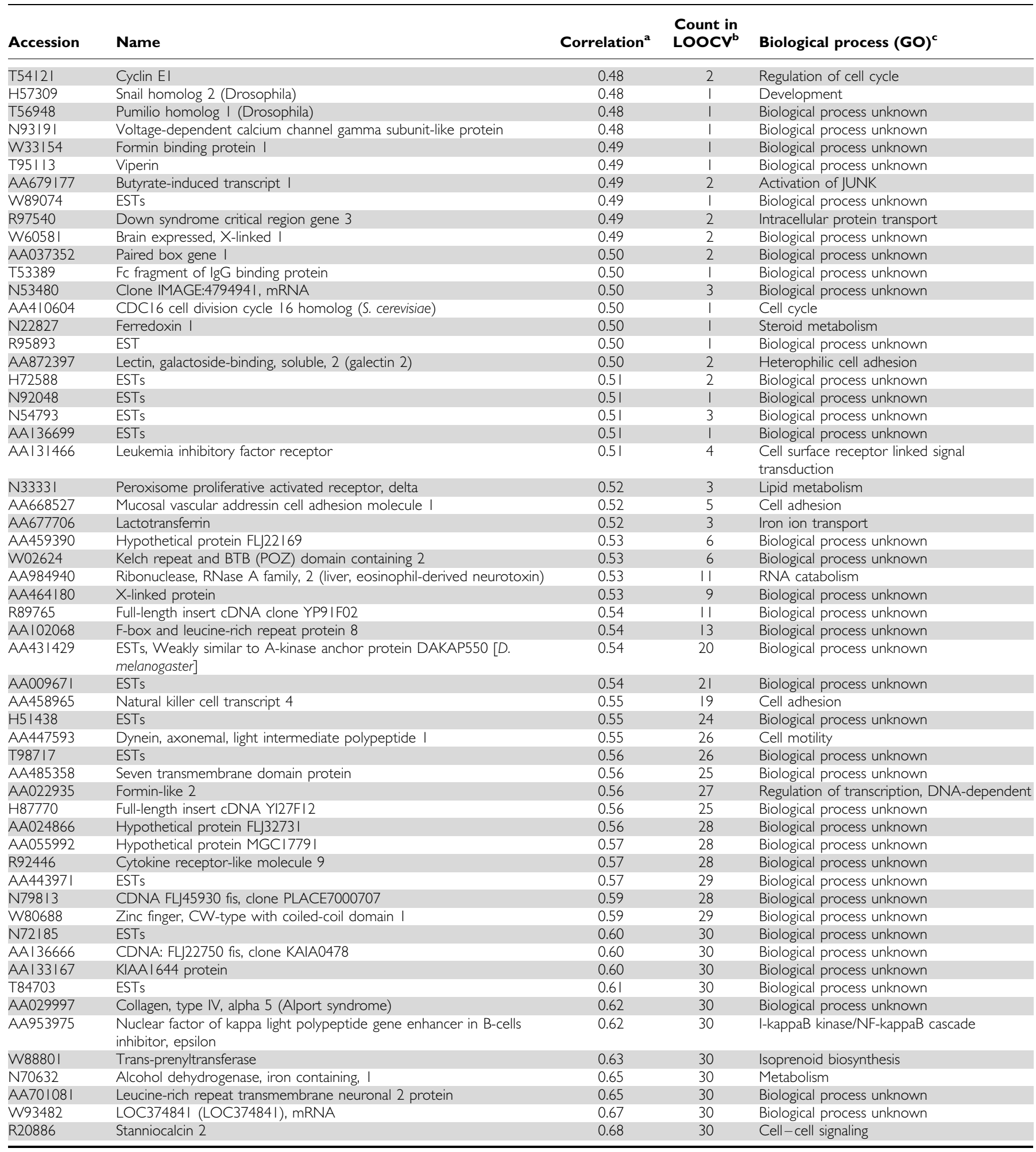

${ }^{a}$ Correlation coefficient between expression levels in 30 colorectal cancer cell lines (Ln) and the corresponding proportion of apoptotic cells after $72 \mathrm{~h}$ exposure to $10 \mu \mathrm{M}$ oxaliplatin (Ln). The correlation of all 9216 genes can be found in our website: www.augenlichtlab.com. ${ }^{b}$ Number of times used in the leave-one-out cross-validation process. 'Biological process from Gene Ontology. 
activity of $\mathrm{NF} \kappa \mathrm{B}$ significantly sensitises colorectal cancer cells to cytotoxic effects of oxaliplatin (Rakitina et al, 2003). In addition, the recently identified apoptosis inhibitor AVEN (Chau et al, 2000) was found to be expressed at higher levels in cell lines that showed reduced apoptosis in response to oxaliplatin.

The cytotoxic activities of oxaliplatin are believed to be linked to DNA damage, and the levels of expression of the DNA repair endonuclease ERCC1 (excision repair cross-complementing 1) have been shown to be inversely correlated with response to oxaliplatin (Shirota et al, 2001; Arnould et al, 2003). Although ERCC1 was not represented in the $9 \mathrm{~K}$ chips used in this study, our microarray analyses identified at least four genes involved in DNA repair mechanisms that were significantly correlated with the ability of oxaliplatin to induce apoptosis in colorectal cancer cells (see Table 1). The histone acetyltransferase HTATIP (HIV-1 Tat interactive protein, $60 \mathrm{kDa}$ ), postmeiotic segregation increased 2like 6 (PMS2L6), general transcription factor IIH, polypeptide 1 (GTF2H1), and the DNA ligase LIG4, showed higher levels of expression in cell lines that are more resistant to oxaliplatin treatment. In fact, at least LIG4 has been shown previously to confer resistance to the related platinum compound cisplatin (Chipitsyna et al, 2004).

In summary, this study investigates the molecular mechanisms underlying the cytotoxic effects of oxaliplatin in colorectal cancer cells in an attempt to identify different means of predicting response to this chemotherapeutic agent. We demonstrate that exposure of proliferating colorectal cancer cells to oxaliplatin

\section{REFERENCES}

Andre T, Bensmaine MA, Louvet C, Francois E, Lucas V, Desseigne F, Beerblock K, Bouche O, Carola E, Merrouche Y, Morvan F, DupontAndre G, de Gramont A (1999) Multicenter phase II study of bimonthly high-dose leucovorin, fluorouracil infusion, and oxaliplatin for metastatic colorectal cancer resistant to the same leucovorin and fluorouracil regimen. J Clin Oncol 17: $3560-3568$

Arango D, Augenlicht LH (2001) New approaches to colorectal cancer treatment. In Recent Research Developments in Cancer Pandalal SG (ed). Vol 3, pp 385-395. Trivandrum: Transworld Research Network

Arango D, Corner GA, Wadler S, Catalano PJ, Augenlicht LH (2001) c-myc/ p53 interaction determines sensitivity of human colon carcinoma cells to 5-fluorouracil in vitro and in vivo. Cancer Res 61: 4910-4915

Arango D, Mariadason JM, Willson AJ, Yang W, Corner GA, Arañes MJ, Nicholas C, Augenlicht LH (2003) c-Myc overexpression sensitizes colon cancer cells to camptothecin-induced apoptosis. Br J Cancer 89: 1757 - 1765

Arnould S, Hennebelle I, Canal P, Bugat R, Guichard S (2003) Cellular determinants of oxaliplatin sensitivity in colon cancer cell lines. Eur J Cancer 39: $112-119$

Ashkenazi A, Dixit VM (1998) Death receptors: signaling and modulation. Science 281: $1305-1308$

Augenlicht LH, Wadler S, Corner G, Richards C, Ryan L, Multani AS, Pathak S, Benson A, Haller D, Heerdt BG (1997) Low-level c-myc amplification in human colonic carcinoma cell lines and tumors: a frequent, p53-independent mutation associated with improved outcome in a randomized multi-institutional trial. Cancer Res 57: 1769-1775

Baker SJ, Preisinger AC, Jessup JM, Paraskeva C, Markowitz S, Willson JK, Hamilton S, Vogelstein B (1990) p53 gene mutations occur in combination with $17 \mathrm{p}$ allelic deletions as late events in colorectal tumorigenesis. Cancer Res 50: 7717-7722

Bertheault-Cvitkovic F, Jami A, Ithzaki M, Brummer PD, Brienza S, Adam R, Kunstlinger F, Bismuth H, Misset JL, Levi F (1996) Biweekly intensified ambulatory chronomodulated chemotherapy with oxaliplatin, fluorouracil, and leucovorin in patients with metastatic colorectal cancer. J Clin Oncol 14: 2950-2958

Bunz F, Dutriaux A, Lengauer C, Waldman T, Zhou S, Brown JP, Sedivy JM, Kinzler KW, Vogelstein B (1998) Requirement for p53 and p21 to sustain G2 arrest after DNA damage. Science 282: 1497-1501

Bunz F, Hwang PM, Torrance C, Waldman T, Zhang Y, Dillehay L, Williams J, Lengauer C, Kinzler KW, Vogelstein B (1999) Disruption of p53 in induces a G2/M arrest and a molecular cascade of events consistent with an intrinsic mechanism of apoptosis. Moreover, the cytotoxic effects of oxaliplatin were shown to be Bax and p53 dependent using and isogenic in vitro system. Importantly, we demonstrate that the expression profile of untreated tumour cells can be used to predict response to oxaliplatin, and that this approach outperforms the accuracy of p53 mutational status as a predictive marker. The efficacy of this microarray-based approach to predict response to oxaliplatin remains to be confirmed in vivo. Collection of tumour samples from suitable patient populations is currently ongoing at our institution to test the value of these approaches, although completion of the study is dependent upon prolonged follow-up periods to assess response to therapy.

\section{ACKNOWLEDGEMENTS}

p53 and Bax null HCT116 cells were kindly provided by Dr Bert Vogelstein (Johns Hopkins University School of Medicine). We also thank Aldo Massimi and Dr Geoff Childs of the Albert Einstein Microarray Facility for their assistance. Oxaliplatin was kindly provided by Sanofi-Synthelabo (New York, NY).

Supplementary Information accompanies the paper on British Journal of Cancer website (http://www.nature.com/bjc). human cancer cells alters the responses to therapeutic agents. $J$ Clin Invest 104: $263-269$

Chau BN, Cheng EH, Kerr DA, Hardwick JM (2000) Aven, a novel inhibitor of caspase activation, binds Bcl-xL and Apaf-1. Mol Cell 6: 31-40

Chipitsyna G, Slonina D, Siddiqui K, Peruzzi F, Skorski T, Reiss K, Sawaya BE, Khalili K, Amini S (2004) HIV-1 Tat increases cell survival in response to cisplatin by stimulating Rad51 gene expression. Oncogene 23: 2664

de Gramont A, Figer A, Seymour M, Homerin M, Hmissi A, Cassidy J, Boni C, Cortes-Funes H, Cervantes A, Freyer G, Papamichael D, Le Bail N, Louvet C, Hendler D, de Braud F, Wilson C, Morvan F, Bonetti A (2000) Leucovorin and fluorouracil with or without oxaliplatin as first-line treatment in advanced colorectal cancer. J Clin Oncol 18: 2938-2947

de Gramont A, Vignoud J, Tournigand C, Louvet C, Andre T, Varette C, Raymond E, Moreau S, Le Bail N, Krulik M (1997) Oxaliplatin with highdose leucovorin and 5-fluorouracil 48-h continuous infusion in pretreated metastatic colorectal cancer. Eur J Cancer 33: 214-219

Deacon E, Pongracz J, Griffiths G, Lord J (1997) Isoenzymes of protein kinase C: differential involvement in apoptosis and pathogenesis. $\mathrm{Mol}$ Pathol 50: $124-131$

Desagher S, Martinou J-C (2000) Mitochondria as the central control point of apoptosis. Trends Cell Biol 10: 369-377

Efron B, Tibshirani RJ (1993) An Introduction to the Bootstrap. New York: Chapman \& Hall

Ehrsson H, Wallin I, Yachnin J (2002) Pharmacokinetics of oxaliplatin in humans. Med Oncol 19: 261-265

Fink D, Zheng H, Nebel S, Norris PS, Aebi S, Lin TP, Nehme A, Christen $\mathrm{RD}$, Haas M, MacLeod CL, Howell SB (1997) In vitro and in vivo resistance to cisplatin in cells that have lost DNA mismatch repair. Cancer Res 57: $1841-1845$

Garg A, Aggarwal BB (2002) Nuclear transcription factor-kappaB as a target for cancer drug development. Leukemia 16: 1053-1068

Giacchetti S, Perpoint B, Zidani R, Le Bail N, Faggiuolo R, Focan C, Chollet P, Llory JF, Letourneau Y, Coudert B, Bertheaut-Cvitkovic F, LarregainFournier D, Le Rol A, Walter S, Adam R, Misset JL, Levi F (2000) Phase III multicenter randomized trial of oxaliplatin added to chronomodulated fluorouracil-leucovorin as first-line treatment of metastatic colorectal cancer. J Clin Oncol 18: 136-147 
Gourdier I, Del Rio M, Crabbe L, Candeil L, Copois V, Ychou M, Auffray C, Martineau P, Mechti N, Pommier Y, Pau B (2002) Drug specific resistance to oxaliplatin is associated with apoptosis defect in a cellular model of colon carcinoma. FEBS Lett 529: 232-236

Gross A, McDonnell JM, Korsmeyer SJ (1999) BCL-2 family members and the mitochondria in apoptosis. Genes Dev 13: 1899-1911

Hayward RL, Macpherson JS, Cummings J, Monia BP, Smyth JF, Jodrell DI (2004) Enhanced oxaliplatin-induced apoptosis following antisense Bcl$\mathrm{xl}$ down-regulation is $\mathrm{p} 53$ and Bax dependent: genetic evidence for specificity of the antisense effect. Mol Cancer Ther 3: 169-178

Johnson CL, Lu D, Huang J, Basu A (2002) Regulation of p53 stabilization by DNA damage and protein kinase C. Mol Cancer Ther 1: 861-867

Johnstone RW, Ruefli AA, Lowe SW (2002) Apoptosis: a link between cancer genetics and chemotherapy. Cell 108: 153-164

Kihara C, Tsunoda T, Tanaka T, Yamana H, Furukawa Y, Ono K, Kitahara O, Zembutsu H, Yanagawa R, Hirata K, Takagi T, Nakamura Y (2001) Prediction of sensitivity of esophageal tumors to adjuvant chemotherapy by cDNA microarray analysis of gene-expression profiles. Cancer Res 61: $6474-6479$

Levi F, Perpoint B, Garufi C, Focan C, Chollet P, Depres-Brummer P, Zidani R, Brienza S, Itzhaki M, Iacobelli S, Kunstlinger F, Gastiaburu J, Misset JL (1993) Oxaliplatin activity against metastatic colorectal cancer. A phase II study of 5-day continuous venous infusion at circadian rhythm modulated rate. Eur J Cancer 29A: $1280-1284$

Li P, Nijhawan D, Budihardjo I, Srinivasula SM, Ahmad M, Alnemri ES, Wang X (1997) Cytochrome $c$ and dATP-dependent formation of Apaf-1/caspase9 complex initiates an apoptotic protease cascade. Cell 91: 479-489

Liu X, Kim CN, Yang J, Jemmerson R, Wang X (1996) Induction of apoptotic program in cell-free extracts: requirement for dATP and cytochrome $c$. Cell 86: $147-157$

Lowe SW, Lin AW (2000) Apoptosis in cancer. Carcinogenesis 21: 485-495

Machover D, Diaz-Rubio E, de Gramont A, Schilf A, Gastiaburu JJ, Brienza S, Itzhaki M, Metzger G, N'Daw D, Vignoud J, Abad A, Francois E, Gamelin E, Marty M, Sastre J, Seitz JF, Ychou M (1996) Two consecutive phase II studies of oxaliplatin (L-OHP) for treatment of patients with advanced colorectal carcinoma who were resistant to previous treatment with fluoropyrimidines. Ann Oncol 7: 95-98

Magrini R, Bhonde MR, Hanski ML, Notter M, Scherubl H, Boland CR, Zeitz M, Hanski C (2002) Cellular effects of CPT-11 on colon carcinoma cells: dependence on p53 and hMLH1 status. Int J Cancer 101: 23-31

Maindrault-Goebel F, Louvet C, Andre T, Carola E, Lotz JP, Molitor JL, Garcia ML, Gilles-Amar V, Izrael V, Krulik M, de Gramont A (1999) Oxaliplatin added to the simplified bimonthly leucovorin and 5fluorouracil regimen as second-line therapy for metastatic colorectal cancer (FOLFOX6). GERCOR. Eur J Cancer 35: 1338-1342

Marchetti P, Galla DA, Russo FP, Ricevuto E, Flati V, Porzio G, Ficorella C, Cifone MG (2004) Apoptosis induced by oxaliplatin in human colon cancer HCT15 cell line. Anticancer Res 24: 219-226

Mariadason JM, Arango D, Shi Q, Wilson AJ, Corner GA, Nicholas C, Aranes MJ, Lesser M, Schwartz EL, Augenlicht LH (2003) Gene expression profiling-based prediction of response of colon carcinoma cells to 5-fluorouracil and camptothecin. Cancer Res 63: 8791-8812

Miyashita T, Reed JC (1995) Tumor suppressor p53 is a direct transcriptional activator of the human bax gene. Cell 80: 293-299

Narita M, Shimizu S, Ito T, Chittenden T, Lutz RJ, Matsuda H, Tsujimoto Y (1998) Bax interacts with the permeability transition pore to induce permeability transition and cytochrome $c$ release in isolated mitochondria. Proc Natl Acad Sci USA 95: 14681 - 14686

Orlandi L, Binda M, Folini M, Bearzatto A, Villa R, Daidone MG, Zaffaroni N (2003) Ribozyme-mediated inhibition of PKCalpha sensitizes andro- gen-independent human prostate cancer cells to cisplatin-induced apoptosis. Prostate 54: $133-143$

Orlowski RZ, Baldwin Jr AS (2002) NF-kappaB as a therapeutic target in cancer. Trends Mol Med 8: 385-389

Petit T, Bearss DJ, Troyer DA, Munoz RM, Windle JJ (2003) p53independent response to cisplatin and oxaliplatin in MMTV-ras mouse salivary tumors. Mol Cancer Ther 2: 165-171

Rakitina TV, Vasilevskaya IA, O'Dwyer PJ (2003) Additive interaction of oxaliplatin and 17-allylamino-17-demethoxygeldanamycin in colon cancer cell lines results from inhibition of nuclear factor kappaB signaling. Cancer Res 63: 8600-8605

Salonga D, Danenberg KD, Johnson M, Metzger R, Groshen S, Tsao-Wei DD, Lenz HJ, Leichman CG, Leichman L, Diasio RB, Danenberg PV (2000) Colorectal tumors responding to 5-fluorouracil have low gene expression levels of dihydropyrimidine dehydrogenase, thymidylate synthase, and thymidine phosphorylase. Clin Cancer Res 6 $1322-1327$

Scherf U, Ross DT, Waltham M, Smith LH, Lee JK, Tanabe L, Kohn KW, Reinhold WC, Myers TG, Andrews DT, Scudiero DA, Eisen MB, Sausville EA, Pommier Y, Botstein D, Brown PO, Weinstein JN (2000) A gene expression database for the molecular pharmacology of cancer. Nat Genet 24: $236-244$

Searle J, Lawson TA, Abbott PJ, Harmon B, Kerr JF (1975) An electronmicroscope study of the mode of cell death induced by cancerchemotherapeutic agents in populations of proliferating normal and neoplastic cells. J Pathol 116: 129-138

Seo YR, Chen EI, Smith ML (2002) Sensitivity of p53-deficient cells to oxaliplatin and thio-TEPA ( $N, N^{\prime}, N^{\prime \prime}$ triethylenethiophosphoramide). Breast Cancer Res Treat 72: 255-263

Shirota Y, Stoehlmacher J, Brabender J, Xiong YP, Uetake H, Danenberg KD, Groshen S, Tsao-Wei DD, Danenberg PV, Lenz HJ (2001) ERCC1 and thymidylate synthase mRNA levels predict survival for colorectal cancer patients receiving combination oxaliplatin and fluorouracil chemotherapy. J Clin Oncol 19: 4298-4304

Skehan P, Storeng R, Scudiero D, Monks A, McMahon J, Vistica D, Warren JT, Bokesch H, Kenney S, Boyd MR (1990) New colorimetric cytotoxicity assay for anticancer-drug screening. J Natl Cancer Inst 82: $1107-1112$

Tassone P, Tagliaferri P, Galea E, Palmieri C, Bonelli P, Martelli ML, Tuccillo F, Turco MC, Venuta S (2002) Oxaliplatin (L-OHP) treatment of human myeloma cells induces in vitro growth inhibition and apoptotic cell death. Eur J Cancer 38: 1141 - 1147

Violette S, Poulain L, Dussaulx E, Pepin D, Faussat AM, Chambaz J, Lacorte JM, Staedel C, Lesuffleur T (2002) Resistance of colon cancer cells to long-term 5-fluorouracil exposure is correlated to the relative level of $\mathrm{Bcl}-2$ and $\mathrm{Bcl}-\mathrm{X}(\mathrm{L})$ in addition to $\mathrm{Bax}$ and $\mathrm{p} 53$ status. Int $J$ Cancer 98: $498-504$

Yang B, Eshleman JR, Berger NA, Markowitz SD (1996) Wild-type p53 protein potentiates cytotoxicity of therapeutic agents in human colon cancer cells. Clin Cancer Res 2: 1649-1657

Zembutsu H, Ohnishi Y, Tsunoda T, Furukawa Y, Katagiri T, Ueyama Y, Tamaoki N, Nomura T, Kitahara O, Yanagawa R, Hirata K, Nakamura Y (2002) Genome-wide cDNA microarray screening to correlate gene expression profiles with sensitivity of 85 human cancer xenografts to anticancer drugs. Cancer Res 62: 518-527

Zhang L, Yu J, Park BH, Kinzler KW, Vogelstein B (2000) Role of BAX in the apoptotic response to anticancer agents. Science 290: 989-992

Zou H, Henzel WJ, Liu X, Lutschg A, Wang X (1997) Apaf-1, a human protein homologous to C. elegans CED-4, participates in cytochrome $c$ dependent activation of caspase-3. Cell 90: 405-413 